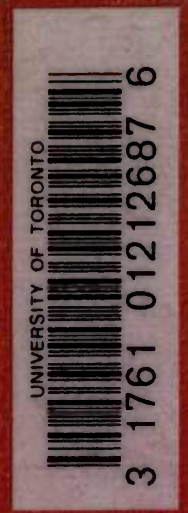


N 
THE CHALLENGE OF AGRICULTURE 



\title{
THE CHALLENGE OF AGRICULTURE
}

\section{THE STORY OF THE UNITED FARMERS OF ONTARIO}

\author{
EDITED BY \\ MELVILLE H. STAPLES \\ EDUCATIONAL SECRETARY OF THE U.F.o.
}

TORONTO

GEORGE N. MORANG

1921 


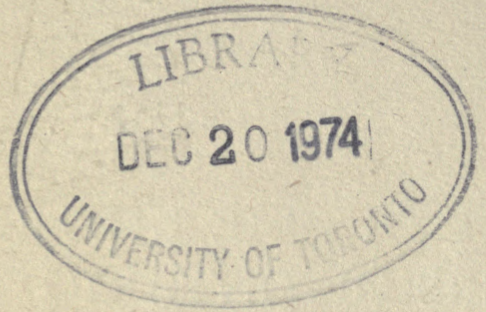

COPYRIGHT, CANADA, 1921

BY GEORGE N. MORANG

TORONTO

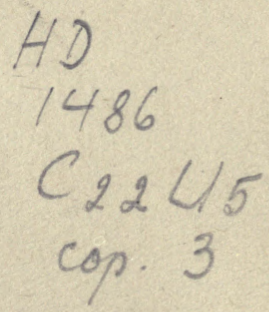


CONTENTS

CHAPTER

PAGE

Foreword ............... 7

I. Early Farmer Organizations........ 13

II. Beginning of The U.F.O...... 38

III. The U.F. Co-operative Company giad 69

IV. The Farmers' Publishing Company. 97

v. The United Farm Women.......... 115

vI. The Farmers in Politics............. 133

viI. Stock-Taking . . . . . . . ..... 156

LIST OF OFFICERS:

First Officers of the Dominion Grange.. 186 Officers of the United Farmers of Ontario................. 186-191

ApPENDIX..................... 192 



\section{FOREWORD}

For almost three centuries after the discovery of America that part of Canada lying west of the Ottawa River was very little inhabited by white men. Adventurers, traders, colonists, and officials who came to seek a fortune, or a home, or both in the New World, clung to the banks of the Lower St. Lawrence or to the Eastern seaboard.

But gradually the resources of the great unsettled region became known, and colonists pushed on into the forest. With infinite labour and unfaltering courage they began to hew out for themselves little plots of land. This movement received a wonderful stimulus about the year 1784, when the United Empire Loyalists began flocking into Canada.

With the coming of the Loyalists, the rapid development of Ontario may be said to have begun. Whatever we may think of the Loyalists' action, we must admire their courage and their tenacity of purpose. "The sufferings of these Loyalists during the long march to Canada were terrible. With their wives and children, and such household goods as could be 



\section{FOREWORD}

For almost three centuries after the discovery of America that part of Canada lying west of the Ottawa River was very little inhabited by white men. Adventurers, traders, colonists, and officials who came to seek a fortune, or a home, or both in the New World, clung to the banks of the Lower St. Lawrence or to the Eastern seaboard.

But gradually the resources of the great unsettled region became known, and colonists pushed on into the forest. With infinite labour and unfaltering courage they began to hew out for themselves little plots of land. This movement received a wonderful stimulus about the year 1784, when the United Empire Loyalists began flocking into Canada.

With the coming of the Loyalists, the rapid development of Ontario may be said to have begun. Whatever we may think of the Loyalists' action, we must admire their courage and their tenacity of purpose. "The sufferings of these Loyalists during the long march to Canada were terrible. With their wives and children, and such household goods as could be 
carried away, they followed the long trail, homeless, friendless, hungry and weary. Frequently they had to beg their bread or accept food from the Indians."

Nor were their troubles over when they reached Canada, for while "every man received free of charge a grant of two hundred acres, with a like estate reserved for each child the Loyalists during early years lived very hard lives, and frequently went to bed at night without knowing where they would find the next day's food. But they bore stout hearts and strong hands, and they persevered, hoping on, and working always.'

While the loyalists were the earliest settlers to come to Ontario in large numbers, they were by no means the only pioneers. It is perhaps not unfair to say that by far the greater part of the heavy toil-some work of opening up the country was done by those who came still later, and without government assistance pushed farther back into the bush. Thrown entirely upon their own resources, almost destitute of means, they braved the loneliness of the "back-woods" and the peril of wild beasts, to make a home where freedom might dwell. Such were the men and women who cleared the land and made it ours; theirs was the hard lot, ours the reward. 
As we go up and down the land today we pass by many cemeteries where lie the remains of these gallant pioneers. More often than not their graves are overgrown with thorns and thistles, the headstones awry, perfect symbols of neglect. Are we not forgetting them and their labors, and accepting our heritage too lightly?

And worse still are we not forgetting the high ideals for which they stood, and the hope that led them, through privation and want, to turn the wilderness into homes where their children might live together amid peace and plenty? Who can look about on the social and industrial fabric of our Province today and say with truth that their dream has been realized?

Still their children struggle on, some tilling the soil, some otherwise employed. From timeto time well marked movements have broken out amongst them, in which the old heroic spirit has arisen in power. One of the most recent of these has developed in the ranks of agriculture. In that movement some men, only a few, see a terrible danger; the majority see a great hope. Whether that hope will be realized, years alone can tell; but let no one mistake a certain indecision of step for lack of resolution. The pioneer spirit is abroad again; the farmer has to find his way. 
An attempt is made in these pages to trace the origin and development of the United Farmers of Ontario. The need for such a book has long been felt, for not only are there many outside the movement who totally misunderstand it, but even within there are those whose views are founded on very meagre information.

In dealing with activities of the day it is always difficult to present facts without some indication of bias. Those who have undertaken to present the history of the U.F.O. cannot hope to have escaped this failing. Almost the only written records to date are the minutes of the various official meetings. Even these records are brief, so that for much that is vital to the story the memories of veteran leaders have had to be drawn upon. For such information, and for painstaking care in presenting it, the best thanks of the editor and of all who read are due to Mr. W. L. Smith, an untiring friend of the farmer; Honorable E. C. Drury, Past-Master of the Grange, first Secretary of the Canadian Council of Agriculture, first President of the U.F.O., and leader of the first Farmer-Labor Government in Ontario; to Mr. W. C. Good, first President of the United Farmers Co-operative Co., Ltd.; Col. J. Z. Frazer, President of the Farmers' Publishing Co.; Mrs. G. A. Brodie, first 
president of the U.F.W.O.; and to Mr. J. J. Morrison, the man of all parts and of all places. Each has provided the material for a chapter on that phase of the subject which he knows best, and his contribution comes in the order in which his name appears. Many others who deserve mention have given assistance but the pleasure of unselfish service must be their reward.

As qualifications for his task, the editor can claim a childhood and many years of manhood spent on the farm, three years' experience as president of a local farmers' club that had for meeting place an obscure hall on a back concession, and a sincere desire to have the aims and the history of the United Farmers placed fairly before the public. For the form of the book and for the final chapter he is entirely responsible. To secure the material has meant much investigation. If the contents prove as interesting and instructive to those who read as the research has to those responsible for preparation, the effort put forth has been well worth while.

M. H. S.

Cavan, Sept. 2nd, 1921. 



\section{THE CHALLENGE OF AGRICULTURE}

\section{CHAPTER I}

\section{EARLY FARMER ORGANIZATIONS}

From time immemorial men have shown a. disposition to band themselves together in groups. Sometimes the group has been a family, sometimes a tribe, sometimes a nation, or again the group has been a still larger unit. Always nations have found their citizens united in sections, formed on the basis of occupation or of temperament. In more recent years such sub-grouping has been especially marked, but more or less it has persisted as far back as historic record furnishes us accurate evidence.

Always when a group has become so marked that it attracts special attention there has been found some cause to which the observer can point as the force which has drawn the members together. Now it has been an expedition against another people for the sake of plunder or revenge; again it has been a coming together for selfpreservation from an aggressive foe; or still 
again it has been a vision of a happier state for mankind where each will be his fellows' equal and where injustice will have vanished. No matter what the end, men have instinctively assumed that in union there is strength and that success is attained in direct proportion to combination and unity of purpose.

Because of their peculiar position in the economic life of their country, some men have seen the advantage of organizing earlier than others. But once this organizing process commenced, it was inevitable that it should spread. Not only did it spread from old countries to new countries, but once having entered a new country it gradually worked through all ranks. Canada like every other country has experienced her share of such development, and in no province to a greater degree than in Ontario. Who of us has not been rendered merry and angry in turn with tales of the exploits of the Family Compact, or of more recent compacts? Among the various classes probably no people moved more slowly in organization than the tillers of the soil, but their time came, and such familiar terms as the "Grange" and the "Patrons of Industry" remind the younger people of today that agricultural organization is no new thing in Ontario.

It has been assumed by most of those who 
have written on the subject that the Grange represented the first attempt by Ontario farmers to found an organization for social and educational purposes, and for the general advancement of agriculture. This generally ac- . cepted view is not wholly founded on fact. The first movement of this kind was inaug- $*$ urated a century and a quarter ago and resulted in the formation of the first agricultural societies which grew very rapidly in number. When first organized, agricultural societies covered a much wider field than they do today. Fall fairs were merely a fraction of their activities. They held fairly regular meetings at which papers were read and discussed on topics including improved farm practice and general matters relating to agriculture. But as time went on the fall fair became the main feature of the societies and about the $*$ year 1850 Farmers' Clubs began to appear to take up the field which the Agricultural Societies were abandoning.

$\mathrm{Up}$ to this period however, the need of an organization to voice the views of the farmers on public questions had not become nearly so pressing as it did later on. Until the third quarter of the last century, agriculture was by far the chief interest in the Province, and farmers had due representation both in the Legislature 
and in the Dominion Parliament. But with the development of other interests and the relative decline of agriculture the situation changed, and farmers commenced to realize the need of an organization through which they could express their views on public matters.

The formation of the Grange was the result of this general feeling. It originated in the United States, and its introduction into Ontario seven years later came by way of the United States. The origin of the Grange across the line was found in causes arising out of the American Civil War. The war had created bitter antagonisms, not only between the North and South, but between factions in the two sections. The main purpose that Mr. Kelly,* the father of the American Grange, had in view was to create an organization that would break down these antagonisms and restore harmony in a country torn by four years of civil strife. $\checkmark$ In Ontario, the Grange was from the first a

\footnotetext{
*Mr. Kelly was a clerk in the U.S. Department of Agriculture at the time he organized the first American Grange. There were six other men associated with him, all officers in the employ of the Government, and one Vineyardist of Wayne County, N.Y. Two of the seven. schooled in Masonry, and one a prominent Oddfellow, framed the Grange ritual, a beautiful composition, rich in imagery. The first meeting of the United States National Grange, held in 1867, consisted of Worthy Master Saunders and Secretary Kelly, these two persons only. Before his audience of one the Master delivered his address which was duly published next day in the press. The first subordinate Grange was organized at Harrisburg, $\mathrm{Pa}$., and the first State Grange in Minnesota. It was not until 1873 that the American Grange really began to make progress. In that year 8,668 subordinate Granges were organized, and in the year following 11,941. With this there came a rush from all quarters to join up, and in one case a Grange was organized in Broadway, New York, with 45 members, representing a capital of as many millions, and composed of prominent bankers, wholesalers, etc. At one time the Grange held fraternal relations with English Co-operative Societies and a few Granges were organized in England.
} 
means of uniting farmers for social and educational purposes, to enable them to make their influence felt in public affairs, and also to co-operate for mutual commercial advantage. The need of a commercial department in a farmers' organization was as urgent half a century ago as at the present day. Long credit $\checkmark$ and long prices were real evils at that period. It was customary for store bills and blacksmith bills to run for a year, and credit prices meant extortionate prices. Not the least of the ser-" vices rendered by the Grange was an effective campaign against this pernicious system.

It was on the second of June, 1874, at London, that the first formal steps were taken towards establishing the Grange in Ontario, and the first annual meeting was held at Toronto in September of the same year. When the Grange first entered the field there were three farmers' clubs in the township of St. Vincent in Grey County, and they at once affiliated with the new organization. The example set in St. Vincent was apparently generally followed throughout the Province. How completely the rural sec- tions were, in a short time, dotted with subordinate Granges is evidenced by the statement that there were no less than sixty-four of them in Grey County alone. The rapidity with which the Grange made progress is shown by the 
official statement that at the third annual meet$\checkmark$ ing the revenue of the Centrai body was reported at nearly $\$ 7,000$, a sum equal to $\$ 20,000$ at the present day. The growth in public esteem is also evidenced by the fact that at the annual meeting of $1883, \mathrm{Mr}$.A. Gifford being then master, the sessions were held in the chamber of the old Parliament Buildings on Front Street, the Master occupying the speaker's chair. During the same session the delegates were entertained

v at the old Government House at the corner of King and Simcoe streets, Hon. John Beverley Robinson being then Lieut.-Governor. The hospitality of the City of Toronto was also extended, the members being carried in sleighs, provided by order of the Mayor, to various points of interest in the city. After a prolonged period of prosperity decline set in, and at the annual meeting of 1898 the receipts for the year were reported as less than $\$ 180$.

Various causes have been assigned for the decline which occurred. Some of these causes were given by the late Robt. Wilkie, then Secre- tary, in a paper entitled "Our Mistakes," read at the annual meeting of 1898 . "The first mistake," Mr. Wilkie said, "was made when the Grange was booming." The large revenues received in the early years were, he said, recklessly spent in many unnecessary ways. 
Had a percentage of the receipts been set apart, and only the interest used, as had been done in the United States, the Grange might, Mr. Wilkie thought, have continued to prosper. A second mistake noted by Mr. Wilkie was in the action of the original promoters of the Grange, who made the financial advantages a prominent inducement for joining. "It was," to quote his own words, "a mistake to refer to these at all." By holding out extravagant promises, two . injurious results were incurred-many joined for commercial gain alone, while in the minds of other classes a fear was created that a farmers' combine was about to be built up which would work injury to established business. Thus, from the start, there was active opposition from without, and when those who had been attracted by the idea of commercial gain did not realize all they had hoped for, they fell away and became a serious handicap.

A third mistake in Mr. Wilkie's opinion was made in holding meetings in the evening. A large proportion of the membership was made up of elderly people, and these soon tired of night meetings following a hard day in the field. This suggests the observation that the Grange failed to keep step with the rising demand for more aggressive leadership. The order does not seem to have retained the 
young men in any appreciable numbers, and without young blood enthusiasm waned.

Mistakes were made undoubtedly, but even if the mistakes were far more serious than all those mentioned by Mr. Wilkie, there would still stand to the credit of the Grange a vast amount of useful service. It represented the first real effort to unite farmers for the protection of their legitimate interests, at a time when political partisanship and sectarian division were much more pronounced than they are at present. It brought together men of all faiths and various political views, upon a common meeting ground, where public questions were discussed and good fellowship promoted.

Besides doing its share in developing a high type of citizenship, it was the originator of the - cash system of trading in rural Ontario. While undoubtedly the practice of the local merchant and blacksmith allowing credit to his customers did much to mitigate hardship in the days of the early settlers, provided the merchant and blacksmith were honest, unscrupulous men were not slow to take advantage of the opportunity it offered for charging extortionate prices, and for eventually acquiring the customer's property. In any case the customer had to pay for the - service. The custom had become so deep rooted that both courage and perseverance were re- 
quired to eradicate it. Its overthrow, therefore, by the cash system was no mean achievement.

Many other measures showing progressive insight stand to the credit of the Grange. One of the first public bodies in the Province to urge that the Hydro Electric possibilities of Ontario be made a means of public benefit rather than of private profit was this association of farmers, and their ideas in this regard were embodied in a resolution at the annual meeting in 1906, and forwarded to Premier Whitney. In the minutes of the Grange we read that "the Premier concurred in the views expressed and promised due consideration." In this instance at least the matter did not end with consideration, but materialized in our vast Hydro-Electric development.

Again, the Grange joined with other farmers' associations in urging upon the Laurier Government the advisability of appointing a Railway Commission to regulate matters of transportation. In the same year a Railway Commission was appointed. Of even greater importance $v$ was their persistent advocacy of a system of rural mail delivery, another accomplished fact. So we might go on detailing endless activities, but we must desist with this one further comment from a recent writer, "About the only im- . portant matter of legislation urged by the 
Grange to which effect has not yet been given is the public ownership of long distance telephone lines."

As noted on a previous page, however, the Grange had failed to keep pace with the demand for aggressive leadership, and thus we find a rival body, the Patrons of the Industry, arising in 1890 , through which the popular feeling found expression. The Patrons, while having commercial features in their organization, were formed mainly for political purposes, and it was this aggressive political activity which caused thousands to drop the Grange in favor of the new organization.

The beginning of the Patron organization took place at Sarnia in 1890. Ten counties were represented at this preliminary meeting, and a Provincial organization was formed with Fergus Kennedy as the first President. The new movement swept the Province like a prairie fire, and soon enlisted the services of a corps of leaders who have perhaps never been equalled in combined power for stirring the farmers of Ontario to action. Among these leaders were Caleb Mallory, for many years President of the organization, T. O. Currie, father of Harold Currie of the U.F.O., J. L. Haycock, afterwards leader of the Patrons in the Legislature, and J. Lockie Wilson. 
The movement received a wonderful impetus at a by-election for the Legislature, held in

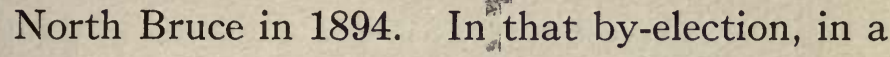
three-cornered contest, David McNaughton, the Patron nominee, was triumphantly returned. In the general Provincial election following, some sixteen Patron members were elected to the Legislative Assembly. The first set-back was experienced in a by-election for Haldimand made necessary by the unseating of Mr. Senn, the Patron member for the Legislature, on a technicality. The Patron was defeated decisively on seeking re-election. This, however, was offset through the election by acclamation of the late David Rogers in Frontenac, in the general election for the Commons which occurred not long afterwards. The greatest set-back of all was sustained when L. A. Welch, secretary. of the Patrons, in a published speech, denounced the leaders for their alleged action in lining up with the Liberals. Another disturbing element was introduced in the Manitoba school issue, but the main injury was worked by the Welch defection, and when the general polling day in the Dominion election of 1896 arrived, all the Patron candidates for the Commons, with the exception of Mr. Rogers (who had been elected by acclamation) went down to defeat.

Still later, when the next Provincial election 
came on, all the Patron members of the Legislature save one were beaten as well, and that marked the practical end of the Patrons as an organized force. But the seed sown remained, and never since has partyism regained the hold it had on the masses of the people before the period when Patronism was in flower.

Some time after the Patron collapse another effort was made in the line of farm organization. This resulted in the formation of the Farmers' Association which, although short-lived, performed a most useful service during the period of its existence. The Grange was then well nigh dormant, and moreover such work as it continued was mainly along social, educational and

- commercial lines. The Farmers' Association was intended to be purely political but not partisan. Its declaration of purpose was simplicity itself :

- "That, while deeming it inadvisable to establish a political party, we believe it is for the welfare of the country that there should be an organization ready to bring its influence to bear to secure and promote the interests of the farmer in matters of legislation and otherwise."

The meeting, at which this organization was effected, was held in the Temple building in Toronto while the Canadian National Exhibition 
was on in the fall of 1902 . The meeting followed a long prior discussion by correspondence in which J. J. Morrison, then on the home farm in the township of Peel, took a prominent part. One hundred and fifty were in attendance, and there was a prolonged debate before organization was finally effected. Jabel Robinson, one of the delegates, strongly urged that those present should unite with the Grange and give renewed life to that organization. A. Gifford, of St. Vincent, advised the acceptance of the platform of the Patrons of Industry as the platform of the new body. Eventually it was decided to create a new organization with the name and the simple platform set forth above.

At this first meeting the Association went farther than the mere adoption of a general statement of purpose. A number of specific resolutions were approved. One of these called $A$ for discontinuance forthwith of the practice of "granting public money to private and corporate interests in the form of bounties and bonuses." At that time both the Dominion and Provincial Governments were granting bonuses to new railway enterprises, and bounties to the iron industry. Up to that period nearly $\$ 230,000,000$ in cash and 54,000,000 acres of land had been granted to railway promoters, and in one year (1902) $\$ 7,915,000$ had been given in bounties on 
+ the output of iron industries. One of these industries actually received, in one year, in Federal and Provincial bounties, $\$ 75,000$ in excess of its entire wage bill in that same year. Another resolution declared "That there should be the strictest regulation of public transportation, and that a commission, with power to fix rates, should be established without further delay." A third resolution pledged the full support of the Association in securing the passage of the Cowan Drainage Bill, (the bill to enable farmers to carry necessary drains across railway lands), and the Lancaster Cattle Guard Bill. In that year the Manufacturers' Association was carrying on an active campaign for an increase in the tariff, and "The Association emphatically protested against any such increase."

Prompt steps were taken to give effect to the resolutions passed. An invitation was extended by it to the Canadian Manufacturers' Association, the Toronto Board of Trade, the Grange, the Ontario Fruit Growers' Association, and the Toronto Cattle Dealers' Association, to send delegates to a joint conference in the Temple Building, for the purpose of considering the advisability of pressing for the appointment of a Dominion Railway Commission. The invitations extended were all accepted. Delegates 
attended from the several bodies named. All agreed that a Commission should be appointed, and a joint delegation was named to wait on the Government at Ottawa and urge the same. The delegation performed the duty assigned, and within a year the Railway Commission was brought into being.

No sooner had the Commission been appointed than further steps were taken. The Farmers'。 Association sent invitations to the Grange, Fruit Growers, and Cattle Dealers, to join with it in preparing a statement of demands for readjustment of freight rates at the first sitting of the Commission in Toronto, and again unity of action was secured. That there was urgent need of such readjustment is made clear by the fact that American grain was then being hauled from Duluth to Portland, largely over Canadian transportation lines, at 11c. per $100 \mathrm{lbs}$., while at the same time the Ontario rate from Midland and other lake ports was $161 / 2 \mathrm{c}$., and the rate on cattle from Chicago to the seaboard was less than from Sarnia to the seaboard. Furthermore, rates within Canada were about $25 \%$ higher than corresponding rates in the United States. These and other facts were presented before the Commission at the hearing in Toronto, and the result was a readjustment in charges, and an improvement in service that 
meant dollars, in hundreds of thousands, every year to Ontario shippers.

It was largely, too, as a result of the educational work carried on by the Farmers' Association, that bounties to iron industries were abolished, and that subsidies to railway promoters became a thing of the past.

Despite all these other activities the Association continued its agitation against the demand for tariff increase as well. The Laurier Government, faced by two opposing forces, manufacturers demanding an increase, ande Ontario farmers joining with their Western brethern (although there was no Canadian Council of Agriculture then) in opposing this demand, resorted to the now familiar practice of appointing a Commission of Enquiry. No sooner had this Commission been appointed than the Farmers' Association made preparations for the presentation before it of a case on behalf of - Ontario agriculture. In the meantime E. C. Drury had become a member of the organization, and when the Fielding Tariff Commission sat in Toronto, in 1906, the farmers' side of the cause was presented by James McEwing, then President of the Association, E. C. Drury and W. L. Smith. The Toronto hearing was followed by hearings at London, Guelph, Brantford, and Peterboro, and at all these places the stand taken 
by the Association's delegates at Toronto was endorsed. Support also came from importers, the evidence of Sir James W. Woods, of the Gordon, McKay Company in Toronto, and of the late G. B. Ryan of Guelph, being particularly effective. Before the Fielding Commission began its rounds all available evidence pointed to a tariff increase. But when revision occurred in 1907 the tariff was not increased.

The Association also maintained an active educational campaign until the Lancaster Cattle Guard Bill and the Cowan Drainage Bill were, in effect, enacted into law. The former measure made railway companies responsible for animals killed on their tracks where negligence of owners of the same could not be proved. The latter compelled railways to bear that part of the cost of farm drains across their property made necessary by the railways' existence.

The creation of the Farmers' Association rendered still another service. The Grange was stirred into greater activity in regard to questions of public policy, and soon there were two organizations in the Province serving the same purpose. It was then wisely decided that the two should unite, and at a joint meeting, when J. G. Lethbridge was Master of the Grange and James McEwing President of the Farmers' Association, amalgamation was arranged for. 
As the Grange possessed a federal charter of incorporation that name was adopted for the joint body.

All this time, the farmers of the Western Provinces had been watching the progress of farm organization in Ontario. More than once, some Western leader had been a guest at annual - meetings in Toronto, but it was not until E. A. Partridge of Sintaluta, Saskatchewan, accompanied by D. W. McCuaig and Roderick McKenzie of Manitoba, appeared at the annual meeting of the Grange in 1909, and appealed for united action, that a Dominion-wide organization of farmers was thought of. Following his appeal, a meeting was held in Prince Albert, Saskatchewan, in 1910, which beside being the annual meeting of the Grain Growers' of Saskatchewan, was also attended by delegates from Ontario, Manitoba, and Alberta. At this meeting the Canadian Council of Agriculture was formed with D. W. McCuaig as President, and E. C. Drury of Ontario as Secretary. A fund to maintain the new body was raised by the contribution of $\$ 100$ from each Provincial Association.

Opportunity for action soon came. Before the end of the year it was apparent that an end long sought by Canadian statesmen was within grasp. A movement in favour of reciprocity with Canada had sprung up in the United States, 


\section{EARLY FARMER ORGANIZATIONS 31}

due to the demand of the great Eastern cities for a more plentiful supply of food-stuffs. It appeared that the advantages of reciprocal trade on a basis favourable to Canada, which had been sought by all great Canadian political leaders in years past, and which every one recognized would be of inestimable value to Canadian farmers, might become an accomplished fact. In order. to take advantage of this situation, the Canadian Council of Agriculture organized a great deputation to wait upon the then Liberal Government at Ottawa, and present the views of the farmers on this important matter. On the night of December 14th, 1910, some 300 delegates, fresh from attending the Annual Convention of the Dominion Grange, which had been held in Toronto on the two preceding days, took train from the North Toronto Station for Ottawa, where they were joined by similar delegations from the West, and by less organized but not less representative delegations from the Eastern Provinces. A convention was held on Thursday, December 15th, in the Grand Opera House in Ottawa, where, after a full day's discussion, certain resolutions embodying the attitude of the organized farmers on several questions of national importance were drawn up, chief among these, of course, being those which related to the question of reciprocity with the 
- United States. On December 16th a delegation, one thousand strong, marched from the Opera House in Ottawa to the Parliament Buildings, where they were received in. the House of Commons chamber by Sir Wilfrid Laurier and his cabinet, to present their views. This demonstration, great in numbers and clear in purpose, had a tremendous effect upon the Government, and upon the country, and as a - result, the then Government sent two of its members, Hon. Mr. Fielding and Hon. Mr. Paterson, to Washington, to open negotiations for a reciprocal trade arrangement with the - United States. To the great surprise of the general public, and perhaps to the astonishment of the Government itself, they came back with something that seemed at first glance almost too good to be true,- - the thing that had been sought by statesmen of all parties so diligently during almost the whole period from Confederation,-reciprocity in natural products, with a corresponding mutual reduction in tariff on only a few manufactured articles.

It must be remembered in thinking of this question, that up to that time the United States had always demanded, in return for the free entry of Canadian natural products into the American markets, that the American manufacturers should be allowed a similar free 
entry into Canadian markets. This, under the policy of protection to manufacturers, which since 1878 had been a part of Canadian policy, had been thought impossible, but in 1910 a new. condition, which has been mentioned before, had arisen. The American cities were clamouring for cheaper food-stuffs. A large part of the American urban population was situated very close to the Eastern Canadian border and was looking upon Ontario as a possible means of supplying their urgent food requirements. A new situation had developed which made reciprocity in natural products without free entrance into Canada of manufactured articles a thing possible of acceptance by the United States, and so Hon. Mr. Fielding and Hon. Mr. Paterson came back with an agreement which had never before been possible of attainment, and which all parties in the past had agreed was to the great advantage of Canada.

The Canadian Parliament scarcely knew what to do with it. Liberals and Conservatives seemed united in its support, and for some weeks no criticism was directed towards the new arrangement. But the protected interests took alarm. Possibly the assertion made publicly by some of the leaders of the Farmers' Movement, who claimed that this break in the tariff wall would prove the entering edge of the wedge which 
would overthrow ultimately the policy of protection in Canada, had something to do with it. At any rate the protected interests decided to oppose the Reciprocity Agreement. The writer has a distinct recollection of riding some miles on a train in Ontario in early February of 1911 , with a prominent Conservative member of parliament, and engaging him in a conversation, in which the latter was asked what he thought of the proposed reciprocity arrangement. $\mathrm{He}$ "replied,- "It is what we have sought for and needed ever since Confederation." Five or six weeks later the writer heard the same member of parliament denouncing, before a specially called meeting, the same reciprocity pact, as an agreement which would ruin Canada and sell her, body and soul, to the United States. Thus is seen the insincerity in the organized opposition to this thing which had been sought by the farmers, but which the protected interests decided must be defeated, because it might possibly prove encouraging to those who would sweep away the stranglehold which these interests had upon the wealth of Canada. With the course of that campaign the public of Canada are familiar. The farm organization was committed to an issue; it had indeed been the force which gave rise to that issue. They found that issue beclouded, obscured by a mass of entirely 
foreign questions which were dragged into the controversy by two parties, one of which was eager to hold office and the other to obtain it. With an appeal to race and creed prejudice, to international hatred, to a dozen conflicting passions, the question at issue stood little chance of obtaining a reasonably popular verdict. The Liberal Government, supporting the reciprocity arrangement, which had been forced upon them by the farmers, went down to defeat, and with it the farm organization received what appeared to be an almost fatal blow.

An informal meeting of those who had been prominent in the movement was called at the Sun office about a week after the election. A few attended, and of those attending, it was the unanimous opinion that nothing further could be done just then through organization to better the condition of the Canadian farmer. As one present rather caustically expressed it,"The farmers have been fools again. Let them fry in their own grease for a while."

In January, 1912, the Grange held its annual meeting in Victoria Hall, Toronto, but few attended, and there was a noticeable lack of enthusiasm. In fact it may be said that in that. year the Grange organization, which represented the only effort being made to provide the farmers of Ontario with a voice in public affairs, 
reached its lowest ebb. It is significant of this state of discouragement and lethargy to note that this annual meeting, which closed on January 25 th, 1912 , was followed by no further meeting until December 17th, 1913, an interval of almost twenty-three months between annual meetings.

The union of the Grange and Farmers' Organization brought about in 1908, and from which so much had been hoped, had failed, and the old saying that "Farmers would not stick," had apparently again been demonstrated.

Perhaps, however, on examination, and with this distance of time between ourselves and the event, we may be able to see the causes which contributed to this failure. In the first place the old Grange, admirable as it was and still is, as an organization, was antiquated and out of - touch with more modern thought. The fact that it was a secret organization with a ritual, in itself constituted objections in some quarters. The further fact that the Grange organization had once been very powerful, but had fallen upon evil days, helped to lessen the public faith in it. It was in fact, not abreast, in thought or in repute, with the times which it sought to serve. The farmers had been seeking to fight a modern battle with bows and arrows." The organization, through which alone the general farming popula- 
tion of the country could be reached, had not proved adequate. Left to form their own. opinions, and guided only by the prejudiced party press of the country, it is no wonder that they were stampeded into giving a verdict foreign to their own interests. Had a strong and active farm organization existed, through which the education of the farm population on this great matter of national policy could have been carried on, the result might have been different. The year 1911, while a disastrous one to the farmers' organization in the Province of Ontario, yet had in it something of benefit, in that it showed the weaknesses which must be avoided in any further efforts to educate effectively the farmers of the Province along the lines of public policy. 


\section{CHAPTER II}

THE BEGINNING OF THE U.F.O.

In the fall of the year 1911, when, after having been made an issue by the farmers' deputation to Ottawa in 1910, Reciprocity was defeated as the result of the befuddlement of the electorate, all seemed lost from the standpoint of the farmers ever being effectively organized, at least in the Province of Ontario. The two older movements, the Grange and the Patrons of Industry, though powerful in their time, had been of short duration in any strength. The effort, made through the Grange and Farmers' Association in conjunction with the Western farmers' organizations, while strong enough to force a great political issue, had not been strong enough, when that issue was put to the test, even to hold its own membership, let alone to influence the general electorate. The next annual meeting of the Grange, held in January, 1912, had been weak and despondent, so weak indeed that almost twenty-three months were allowed to pass before the next annual meeting was called, in December, 1913. The farmers' cause in Ontario was never at a lower ebb.

A few men, however, held to the faith, and 
made up their minds that something could be done, chiefly because they believed that something ought to be done. On a bright, cold Saturday in the late fall of 1913 , with a hint of coming winter in the air, four farmers came to Toronto to discuss the seemingly hopeless situation, and, if possible, to devise some means for its betterment. These four farmers were, W. C. Good, Col. J. Z. Fraser, J. J. Morrison and E. C. Drury. They had expected to meet in the office of The Weekly Sun, their one journalistic friend, but being rural folk, accustomed to work six days in the week, and a part of the seventh, they had reckoned without knowledge of the city man's habit of taking Saturday afternoon off. They found the Sun office closed and deserted. They were much disappointed, it is true, for they had expected not only a sheltering roof, but comfort and counsel from their friend, the editor. They had, however, come long distances, at a considerable sacrifice. They could not afford to go home without something accomplished. They walked from the deserted office of the Sun to the Kirby House on Queen Street West, secured a room, and held their conference, going back to their farms the same evening. The result of that conference was, a few months later, the birth of the United Farmers of Ontario. 
The idea on which was based the plan for the formation of the new organization, came from J. J. Morrison, and, in order to understand it, - we must turn back some five years. In the year 1908 , when the Grange, after its union with the Farmers' Association, was showing some signs of aggressiveness, the Ontario Department of Agriculture began to organize Farmers' Clubs ' over the Province. These Clubs were formed by the Department to promote advanced methods of agriculture, and received some aid, in the way of being provided with speakers and regular visits from the district representatives wherever possible, but it is significant that in them all * political discussions were forbidden. Not a few thought that these clubs were designed to stifle the discussion of public questions by the farmers, and to head off the Grange in the work it was attempting to do in the formation of rural public opinion. So strong indeed was this belief that one agricultural journal in Ontario (not the Sun) published a cartoon wherein the then Minister of Agriculture was shown in the act of knocking the Grange on the head with a bludgeon labelled "Farmers' Club." These clubs, thus organized, had not thriven as was \& expected. They had no bond of union, no great purpose, and interest in them was inclined to flag. They had, however, a simple democratic 
form which appealed to the people, and while many of them (like David Harum's calf), had "just gi'n out" from sheer lack of interest, a fair number were alive and were centres of community interest. Morrison's idea was put in few words: "Let's steal the clubs," said he. (This was Brother Morrison's first venture in Bolshevism.)

Much letter writing followed this first informal conference. Officers of the Farmers' Clubs, Granges, Live Stock Associations, Co-operative Fruit Associations and any others who, it was thought, could be interested, were communicated with. In general the response was satisfactory. A few small preliminary meetings were held during the winter of 1913-14, and finally a conference was arranged to take place in the Labor Temple on March 19th and 20th, 1914, at which the question of creating a new Provincial organization was to be dealt with.

This organization meeting was quite largely attended, some 300 delegates crowding the room which had been secured for the occasion. At the beginning of the conference a considerable divergence of opinion was manifest. Nearly all agreed that an adequate provincial organization ought to be formed, but there were many who doubted the ability of the farmers to stick, and who thought, in view of past experience, 
that such a movement in Ontario would be foredoomed to failure. Some encouragement was found, however, in telegrams received from the already successfully organized farmers of the West. The tenor of these telegrams is seen in one sent by the United Farmers of Alberta, and signed by W. J. Tregillus of Calgary. This read as follows:- "The Provincial Board of Directors, United Farmers of Alberta, in meeting assembled, send greetings and wish farmers of Ontario every success in their deliberations and efforts to organize on Provincial lines, and look forward to the day when the farmers of Canada shall be organized for mutual benefit from the Atlantic to the Pacific."

* The chief speaker of the convention was Roderick McKenzie of the Manitoba Grain Growers' Association, who explained lucidly and forcefully the birth, progress and aims of the Grain Growers of the West. Those who had been active in the various farmers' organizations represented in the meeting followed $\mathrm{Mr}$. McKenzie. Gradually doubt changed to faith and hope, and at the end of a two days' conference, twin organizations came into being, The United Farmers of Ontario, an organization whose aim was to provide the farmers of Ontario with means for self-education, not only in matters pertaining to the business of production, as 
other societies had done, but also along broad lines of citizenship, the study of public questions, and the giving to the rural people a means of making their opinions felt in these matters, and the United Farmers' Co-Operative Company, designed to aid the farmer in his business of buying and selling.

The reader may wonder why this dual organization was necessary, why it was necessary that the United Farmers' Association and the Company, closely allied as they were and are, should have been two separate and distinct organizations. The answer to this question is, that although these two serve practically the same people, their aims and methods are so different and indeed divergent, that if it were attempted to combine them, nothing could be effected but mutual hindrance. The United Farmers of Ontario has for its sole aim the raising of the rural people to a higher plane of citizenship. Recognizing the importance of the farmer in the life of the nation, it aims to give him a knowledge of public questions, and an influence on national life commensurate with his importance. Such an organization, educational in its nature and sometimes, of necessity, becoming a propagandist for those things in which it believes, is obviously unfitted for the work of buying and selling. On the other hand the Company is a 
matter of commercial advantage. Its work is to make possible better business for its members. It must employ the most capable men available for its work, it must enter into commercial relations in many directions. To burden it with educational or propagandist work would destroy it. It is evident that if each of these organizations is to function properly, it must be kept separate and distinct from the other.

The business company and its work is vastly important. On its success in a great measure depends the success of the farmers' work. Better business means greater profit, better farm homes, better rural schools, better chances for farm children, and in a large measure the ability of rural sections to hold their proper proportion of the population. But in spite of these undoubted facts, the opinion of the writer is that a still greater work is and can be done through the educational part of the organization. It is vitally important, both for himself and the nation, that the farmer should be possessed with high ideals of citizenship, founded on knowledge and public spirit. Such is the work which has been done with some effectiveness by the United Farmers, so that at the end of seven years' effort the farmers are probably better informed on questions of public policy than any 


\section{THE BEGINNING OF THE U.F.O. 45}

other class in the community. Such is the greatest work that the future can hold.

The year following the organization meeting was one of some discouragement, but on the whole brought satisfactory results. The first executive meeting of the new association was held on April 13th, 1914, at the Carls-Rite Hotel. Matters of general policy were considered and a plan was outlined by which it was hoped that the merits of the new undertaking would be brought before the people. The treasury, however, was almost bare, and had it not been for generous aid given to the new movement by the farmers' organizations of the West, who had loaned to it the sum of $\$ 1,000$ to be spent as seemed wisest, and by Mr. S. A. Beck of Cayuga, who gave a generous amount to aid the organization, the outlook would have been still more discouraging. As it was, during the first two years, and indeed to the present time to a very large degree, the success of the movement depended upon voluntary and unselfish effort on the part of those who believed in it. This handful of men went here and there throughout the Province, generally in the neighborhood of their own homes, attending club meetings, calling meetings for the purpose of organization, and everywhere preaching the need and advantages of a province-wide farmers' association. 
In snow and storm, in discomfort and fatigue, often paying their own expenses, these men carried on their work, and the success of the movement may justly be attributed to their unselfish and, in many cases, almost unrecognized efforts.

The year 1914, however, brought results. - The first annual convention was held on February 25 th, 1915 , in a small room adjoining the dining hall at the Carls-Rite Hotel, Toronto. The president of the organization at this first annual meeting was E. C. Drury, who had been elected to the office at the organization meeting in the previous March. The year showed encouraging progress. Fourteen new branch organizations had been formed; fifteen old Government Farmers' Clubs had affiliated, while three Granges and two other associations had come in. Thus, the first year witnessed 44 local organizations with approximately 2,000 members joining up. The trading company up to this time, it is true, had shown comparatively little activity, but the spirit of success was in the air, and among the one hundred and fifty delegates who attended the first annual meeting and listened to the interesting and thoughtful programme there was a distinct spirit of optimism. They went out from this meeting missionaries of the movement. The good work was 
continued. At this first annual convention; R. H. Halbert, who had demonstrated his * ability and aggressiveness in the work of organization of Dufferin County, was elected president of the United Farmers of Ontario, the first president, E. C. Drury, having refused to allow his name to go up for re-election on the ground that he believed the organization would be strengthened through pursuing a policy by which the personnel of the important offices would be subject to frequent changes.

At the second annual meeting, held in February, 1916, in the Labor Temple, still further . progress was reported. The Association now numbered nearly 5,000 members, eighty-two new clubs having been added since the last convention, fifty of them newly organized, and the remainder local Granges which had come in. The trading company by this time had attained some little measure of success, though in a comparatively small way. The delegates to this convention were even more optimistic than at the first annual convention, and the discussions showed an active and healthy interest in public affairs. It is significant to note that at this convention a resolution was passed asking for prohibition of the liquor traffic, both Dominion and Provincial. Thus, in its early days, the farmers' organization pronounced unequivo- 
cally on an important moral and political question. Immediately following the second annual meeting, a directors' meeting was held, and further plans for extension were laid. As a part of these plans, J. J. Morrison was appointed an organizer, and, while the finances of the association were not at that time strong enough to pay anything like adequately for the work undertaken, an allowance was made to remunerate him in some manner for the time and energy spent on this work. A committee was also appointed to prepare literature and to hold district conventions.

- Up to this time there had been no formal affiliation between the United Farmers of Ontario and the Western organizations, though the most cordial relations had been maintained.

At a second directors' meeting, held on April 20th, 1916, the United Farmers formally affiliated with the Canadian Council of Agriculture. It is significant, too, that at this meeting, the directors, having taken stock of the whole movement, both as to the Company organized for commercial purposes and as to the educational part of the movement, received the report of a special committee which pointed out that too much attention was being paid to the commercial activities and not sufficient to educational and social interests. 
In bringing in their recommendations they divided their report into two sections, one dealing with the question of policy and the other outlining a platform, the adoption of which they believed would serve to crystallize the thought of their members. Their report was rather comprehensive, and, since it had such a marked influence on the future of the movement, parts of it will bear quotation here.

The clauses dealing with the question of policy recommended:-

1. "That the association, in addition to the annual convention, hold a series of district conventions each year, the local arrangements for which shall be left in the hands of local committees.

2. "That a monthly or semi-monthly paper be issued for distribution among all the locals as a means of keeping them in close touch with the whole movement. That pamphlets explaining how to conduct meetings, and also explaining measures advocated in the platform be prepared and sold to the locals at cost.

3. "That the association shall aim to finance its own activities as far as possible ..... We do not approve of the suggestion that the association should commercialize its activities in any way.' 
The articles of the platform, as recommended, were:-

1. "The nationalization of railways if a special committee that is to be appointed to consider this matter should recommend in favor of nationalization.

2. "The initiative and referendum.

3. "A tax on unused waterpowers according to their value.

4. "A provincial telephone system such as exists in Manitoba.

5. "A tax on land values to meet the taxation that will be necessitated by the War, so that the high priced city land may be made to contribute its share of the burden of taxation.

6. "That legislation be introduced suitable to the establishment of co-operative associations."

Thus we see that early in the movement the faith of those promoting it was pinned more to the work of education of the rural community than to the success of the affiliated Co-operative Company. This proposed platform was sent out for discussion to the clubs throughout the country and was passed on to the next convention for consideration. During the discussion its form was considerably altered, but we find in this initial declaration the germ of those principles which have been embodied in the farmers' platform as we now know it. 
The third annual convention was held in St. James' Parish Hall, beginning on February 28th, 1917. The movement by this time had grown. immensely, numbering some two hundred clubs and eight thousand members. Enthusiasm marked the gathering. The discussions were of a high order, and a spirit of determination to make the movement succeed was manifest everywhere. The reports of the delegates showed that throughout the Province the local organizations were beginning to function in the education of the rural public on questions of national and provincial moment. The clubs were undertaking with vigor that work which they have so successfully prosecuted since then, and the membership throughout the country was taking a keen and intelligent interest in public questions. Significant of this fact, as reflected $r$ in the convention, was the appointment of a legislative committee to keep track of legislation proposed or needed, in the Dominion or the Province, and to take such action as might be found necessary. At a directors' meeting in September of this year, 1917, the question of establishing an official organ for the movement was taken up. This question had been discussed many times previously, but it had not been thought that the organization was strong enough to support a paper. At this meeting, however, a 
committee was formed to investigate the possi, bilities of such a paper. At another executive meeting held on October 5th, 1917, a resolution was passed protesting against the fixing of prices of farm products as had been done in the case of wheat and cheese and leaving the prices of other commodities unregulated.

The fourth annual convention was opened in December, 1917, again in St. James' Parish Hall, and showed most satisfactory progress both as to numbers and enthusiasm. The organization now numbered three hundred and fifteen local clubs and twelve thousand members. The tone of the convention was quite equal to that of the previous one, and, the quality of the discussions, if anything, was superior. The rural people, through their organization, were evidently taking an ever-increasing interest in public affairs, which was shown by an amendment added to the constitution providing that a director should be appointed for every Dominion electoral division in the Province. In this way a much more representative body was provided for, and the board of directors, though large and in some senses unwieldy, became truly representative of thought all over the Province. Also a definite centre of activity was provided in every electoral division.

Meanwhile, another force was in operation 
which had a tremendous effect in demonstrating to the farmers of the Province of Ontario their great need of an adequate and powerful Provincial organization. In the Fall of 1917 a Dominion election had been run upon the issue of Conscription. Of the politics in this election. we need have nothing to say, but it is a fact that the farmers of the Province had been definitely assured by the representatives of the party which won the election, that in the event of their election and the carrying of the conscription issue, the farms would not be denuded of necessary help. Further, in March, 1918, the then Dominion. Minister of Agriculture, Mr. Crerar, had called in Toronto, a meeting of representative farmers of the Province of Ontario and had urged upon them the absolute necessity of the greatest $\checkmark$ possible production of food-stuffs during the coming season. The farmers had already re-sponded to the utmost in production, and, though it may be urged that in doing so they had been partly influenced by the war prices of food-stuffs, yet it is well to remember that unlike most classes of producers, the price of their products had been regulated so as to prevent their attaining the high levels that without regulation they would have undoubtedly reached, and that in responding to the call for production they had really put forth an heroic effort which involved in 
many cases the farm women, already overworked, undertaking to help in the field work of the farm. In fact, there were many cases where health suffered because of this over-work. Nevertheless, in response to Mr. Crerar's appeal and the statement of the Government through him, that the success of the war would probably depend upon food production, in the Spring of 1918 plans for still greater production were laid. The carrying out of these plans involved the use of many thousands of farm boys whose cases had been considered before the Conscription tribunals during the winter, and who had been given exemption for this very purpose. Then, in the midst of seeding operations, these exemptions were cancelled.

It has been charged by the detractors of the farmers' movement, that the strong agitation which swept the Province because of the cancellation of these exemptions showed an unpatriotic and selfish spirit on the part of the farmers. Before this conclusion is accepted it is well to remember several facts. The beginning of the war had found the farms seriously undermanned and still more seriously underwomaned. For years, owing to the prevailing economic system, farming had been less profitable than it should have been, with the result that the trend of population had been strongly 


\section{THE BEGINNING OF THE U.F.O. $\quad 55$}

toward the towns and cities. The year 1914, when the war broke out, found scarcely more than one man to one hundred acres of Ontario farm land, a population not sufficient to handle $\checkmark$ the necessary work with any degree of comfort. With the progress of the War came the call for: volunteers, and the young men of the farms, though they were needed at home, and their going often involved the further burdening of already overburdened shoulders, had enlisted freely. It is true that the rural districts never got full credit for this, for the reason that many of these young men enlisted from nearby towns, but the fact remains that the country districts responded most generously. It is also to be remembered that less than six months before the exemptions were cancelled, in the election campaign of 1917, the farmers had been assured by the members of the Union Government then seeking election, as has already been pointed out, that farm help would not be conscripted, and that if any of these were taken they would be honorably returned to the farms. Further, only a few weeks had passed since the Minister of Agriculture of this same Government had urged upon the farmers that the deciding factor of the war would be food production, and that their duty was to push production to the limit. With all these facts 
in view, it is no wonder that the farmers believed that a great mistake was being made which it was their duty to set right. Of course they were told that the serious reverses on the Western front in the early spring of this year were sufficient reason for the breaking of solemn promises, as undoubtedly would have been true had it been possible for the newlyraised forces to be trained and transported across the ocean in time to meet the sudden emergency, or had they not been more urgently * needed elsewhere. The farmers, however, realizing that it would take at the least several months to train and transport these men, and that the emergency would have passed, with whatever result, before they could reach the front, and seeing further, that very many acres whose produce they had been told was urgently needed to save the Allies from famine, would lie fallow because the men necessary to work them had been conscripted,- - the farmers came to the conclusion that a wrong and foolish policy was being followed, and that it was their duty to protest. The correctness of their conclusion was shown by the event. Farm operations were seriously disturbed and production considerably curtailed, while comparatively few of the young men whose exemptions were cancelled ever reached the front. 
Held in the grip of the national organization for war, the farmers discovered their impotence when it came to a matter of giving effective expression to their opinion. They began to cast about for some instrument through which they might take action. The only instrument to hand was the association of the United Farmers, and to this they turned as the one organization giving a lead to agriculture. Letters poured in . to Head Office from members and non-members of the association, and the result was the journey of a huge delegation of farmers to Ottawa to wait upon the Government on May 14th. The details of this visit will be found in a later chapter. Just here it is sufficient to state that their efforts availed nothing by way of securing a modification of the order-in-council, that their representations were practically ignored, and that they returned home very much angered, not so much because they had failed in their mission, as because of the cool reception tendered them by the Government and the abuse showered upon them by the press. From that day there was never any further doubt in the minds of farmers as to the necessity of their having a strong organization of their own. No matter how much they might differ as to its method of functioning, they agreed that it was necessary.

On the strength of this general feeling and to 
consider further what immediate action farmers should take, a special convention of the United Farmers was called to meet in Toronto on June 7th. A room in the Labor Temple had been engaged for the occasion, but before noon so many delegates had assembled that the accommodation was altogether inadequate, and the afternoon session was held in Massey Hall. This large hall, accommodating nearly four thousand, both afternoon and evening was packed to the doors. Seldom has any chairman beeen confronted with a more difficult task than that which faced R. H. Halbert in his efforts to maintain order and to expedite business. Literally, hundreds of resolutions had been sent in by clubs through their delegates, and these delegates insisted on presenting their resolutions to the meeting. Often more than a dozen delegates were on their feet at once determined to speak. Had it not been for the wit and the commanding voice of the president little progress could have been made.

- Printed on a large streamer hanging across the front of the hall were the three words, "Organization, Education, Co-operation." Never before had the import of these three words so come home to the mind and heart of the farmer. In spite of his apparent failure, he found courage in the comradeship of his fellow 
agriculturists, and instinctively he laid firm hold of the truth that in union there is strength. From this convention almost every delegate went home an apostle of organization, determined to enlarge his club and to create new clubs.

But before we leave this convention, there are several features to be noted that have since played a large part in the movement. First amongst . these was the presence of representatives from the farmers of Quebec. Up until this time the same feeling of separateness, which was found in the political sphere between representatives of Ontario and Quebec, had extended to the ranks of agriculture. When the great delegation from. Ontario went to Ottawa in May and met there a similar delegation fom Quebec, these farmers made the mutual discovery that their interests were wonderfully the same. More than one delegate was heard to express the view that they had been kept apart in the past through misunderstanding, and for that misunderstanding designing politicians were responsible. Whether this view be correct or not, a new feeling of brotherhood grew up and led to Mr. Monette being invited to speak at this convention on behalf of the farmers of Quebec. The happy relations thus engendered have been continued ever since, and it is the hope of farmer leaders in both provinces that nothing may arise to disturb 
the lead thus given to other classes in the practice of harmonious action between these two peoples.

Again, a great impetus was given to the Farmers' Publishing Company. As noted before, a committee had been appointed in the previous autumn to investigate the possibilities of establishing a paper. Patiently and carefully this committee carried on its work and brought in a report to the Board of Directors of the U.F.O. As a result of that report the Farmers' Publishing Company had been formed. The new Company, acting energetically, had, in April, purchased The Weekly Sun, an established farm paper published in Toronto. From the time that the company was formed, the directors had worked unceasingly to sell capital stock, which was offered at twenty-five dollars per share, but in spite of the widespread desire for a farmer's own paper, capital was slow in accumulating. At this convention, however, a new opportunity was presented.

Between enthusiasm for the cause, and resentment at the daily press, because of the biting accusations contained in its pages, the farmer was willing to go almost any length to secure for his cause a reliable mouthpiece. The delegates, therefore, in response to an appeal for subscriptions for the paper, and also for sub- 


\section{THE BEGINNING OF THE U.F.O. 61}

scriptions to the capital stock of the Publishing Company "came across" most heartily, so that from that day the farmers' paper has been on a sound financial footing.

While the paper was receiving its share of attention, another equally important move was under consideration also. For several years it. had been evident that, to obtain the best results, the women of the farm must be more closely linked up with the movement. In almost no* other industry are women so dependent upon the men of their homes for assistance and company, if they wish to go from their homes to visit friends, or to attend meetings. Very frequently therefore, they go together, especially if their journey be to attend an entertainment or a social evening. The farmer's club is essentially a social and educational institution, and on that score the presence and co-operation of women was desirable. But more particularly, encour-aged by the democratic ideals of the movement, women were demanding and men were requesting that women share in the discharge of the affairs of State, and become members of the association. Equal responsibility presupposes equal preparation and activity, and so steps were taken to bring the women actively into the U.F.O. Not many weeks after this convention, a meeting of representative women of Ontario 
was held in Toronto, at which was formed the United Farm Women of Ontario, the distinctive women's arm of the movement.

It was only natural that the delegates in their discussions, at the special convention on June 7 th, should pay a good deal of attention to politics. Less than a month before, many of them had been at Ottawa, and they were still smarting under their rebuff, and under the abusive criticism of the press. A great feeling of disappointment in their elected representatives was expressed on all sides. Somehow a great gulf had arisen between the parliamentary representatives and their farmer constituents, and a demand was then and there voiced at this convention that at the earliest opportunity there should be elected to Parliament a number of men from the farm who would understand the farmers' needs, and who would not refuse to listen to their constituents, if they came to wait upon them with some important petition or repre* sentation. While no definite policy in regard to political action was adopted, there seems little doubt that a majority of the delegates went home convinced that any effort to work through the old parties was almost hopeless and that the one alternative was independent action.

During the summer months, organization went 
on apace, and before the annual convention, two meetings of directors should be noted. On September 4 th, 1918, it is recorded in the minutes that Mrs. Brodie, Mrs. Foote and Miss Griesbach, the provisional executive of the newly formed women's association, met with the men and reviewed their activities and their prospects. On the strength of their recommendations, the treasurer was instructed to pay organization "expenses up to the limit of the resources." Then on October 28th a joint meeting of the boards of directors of all the branches of the U.F.O. was called at Toronto. The association. was now growing so rapidly, and spreading out into so many lines of activity, that the wholequestion of reconstruction required careful consideration. Amongst all the other features the one that demanded most careful attention was the attitude of the U.F.O. toward political action. Up to this time the U.F.O. had taken no direct hand in politics officially, but just previous to this meeting the farmers of Manitoulin, where a by-election was to be held shortly, had shown = that they were not disposed to wait for official action, but had declared their intention of putting an independent candidate in the field. After full discussion the following motion was passed: "That we do not at present decide upon forming a farmers' party, but that we 
recommend the selection of farmers' candidates in rural constituencies at by-elections, and that the representatives from the U.F.O. to the Canadian Council of Agriculture report back to the board the attitude of that body toward this subject." Not long after the Manitoulin farmer candidate was elected.

The annual convention, commencing December 18 th, 1918 , is remembered chiefly because of two resolutions passed, which had a vital bearing on the policies of the Farmer-Labor Government later on. While the secretary could report a membership of twenty-five thousand, grouped in more than a thousand clubs, the actual attendance at the convention was small. This was on account of the "Flu", that dread disease which was then raging in the city and kept many away through fear of contracting the malady and carrying it home. At one time the idea of a convention was abandoned, but eventually the annual meeting was held, and amongst other business transacted the two resolutions referred

t to were adopted. They were as follows: "That there be a plank in the provincial platform of the U.F.O. favoring local option in taxation," and, "That this convention views with alarm the proposed hydro-radial policy involving the expenditure of millions of dollars on a railway intended in many instances to duplicate existing railways, 
and that the Legislature be requested to move slowly in this matter." In these resolutions we have the first expression of ideas, so far as the U.F.O. is concerned, that have played an important part in the activities of the FarmerLabor government.

Owing to the prevalence of the "Flu" in so many parts of Ontario during the winter of 1918-19, club activities were seriously interfered with, but in spite of that, the clubs increased in numbers, and the business company extended its operations also. Besides this, rather more attention than formerly was being paid to the stimulating of debates and the study of public questions. The fruit of this work was seen in a series of events culminating in the monster convention of 1919, the most enthusiastic gathering the farmers have yet held. In the early autumn, the then Provincial Government, under the leadership of Sir William Hearst, decided to go to the country for re-election. No sooner was this generally. understood, than the Province fairly bristled with United Farmer candidates. For the whole story of what took place, the reader must wait until he reaches a later chapter, but just here we note that when the results of the polling on October 20th were made known, the farmer group was found to be much the largest in the House. In due time a Cabinet was formed, and on the evening 
of Dec. 17 th, the second evening of the annual convention, a tremendous rally was arranged. On the great platform sat Premier Drury surrounded by his Cabinet and all the elected farmer members, and behind them sat hundreds of women, members of the U.F.W.O., while in the vast auditorium every available space was occupied by someone anxious to hear and see. Some wag, epigramatically inclined, was heard to remark during the evening somewhat caustically, "the only bewhiskered farmer in the Cabinet isn't a farmer," (referring to Attorney-General Raney). Each member of the Cabinet spoke very briefly, outlining some of the work he hoped to accomplish during his term of office in his own department. No more sympathetic and enthusiastic reception could have been tendered anyone than that accorded to the new Premier and his Cabinet on that evening. All went home feeling that a new era had dawned on agriculture and that once more farmers were coming to their own.

The following year was remarkable chiefly for the great number of new clubs added, and also for the gratifying expansion in the co-operative company. At the annual convention the secretary could report more than fifteen hundred clubs, with a total membership of approximately sixty thousand men and women. In addition to this, 
there had been created as a direct result of the activities of a few United Farm Women, a special organization for bringing in the young people between the ages of thirteen and twenty. The year had been marked by some rather keen controversies between the leaders of the Provincial Government and the leaders of the U.F.O. Outside electors and the party press took this as a sign of weakness and of disintegration. Such it has not yet proved to be, and by most people it is regarded as an indication of virility and independent thought, most wholesome in representative government. Time alone can reveal the outcome of this rather new feature introduced into the operation of a political group.

But whatever form the movement may take in the future, undoubtedly the executive were on solid ground, when, shortly before the annual convention, 1920 , they created a special department at Head Office whose function it is to encourage the development of local talent in the clubs by stimulating entertainments, debates, and the study of questions of public policy, and by furnishing reliable information on questions of interest, when desired. The ideal of the U.F.O. is a high and enlightened citizenship. To realize that ideal requires careful and sincere leading. By developing those features of the organization which aim at breaking down 
ignorance, isolation, and prejudice, the United Farmers of Ontario can do much to fulfill the mission which they have so splendidly begun. Just how each wing of the organization contributes to the general life of the movement, we are now to examine in more detail. 


\section{CHAPTER III}

THE U.F. CO-OPERATIVE COMPANY

Although The United Farmers Co-operative. Company, Limited, has been incorporated since February 7 th, 1914, a very hazy idea as to its independent existence still exists in the minds of many, and it is variously misnamed the U.F.O., the U.F.O. Co-operative Company, and so forth. From the beginning, however, it has had a separate existence, quite apart in point of law, from that of the U.F.O. In accordance with plans already mentioned in Chapter II, the U.F. Co-operative Company was incorporated with provisional directors in February, 1914. The original applicants for incorporation . were W. C. Good, Fred Luck, R. J. McCormick, W. T. McCormick and John Bowers, all farmers living in the County of Brant. George Keen, Honorary Secretary of the Co-operative Union of Canada, without charge looked after the legal and clerical work, prepared the by-laws and secured the charter.

The scope and purpose of the United Farmers Co-operative Company is stated in the following terms in the articles of incorporation: 
(a) "To produce, manufacture, import, export, buy, sell, deal in and deal with all cereals, fruit, vegetable, animal or other products of the farm, all products or by-products thereof and all machinery, implements, goods, wares and merchandise which may be used in the production and manufacture of products of the farm and all articles, substances and things which may be utilized in the said production or in the maintenance, cultivation, improvement and development of farms, and (b) Without restricting the generality of the foregoing expressions, to carry on the business of farming in all its branches on the co-operative plan for the mutual advantage, accommodation and convenience of the members of the Company."

From this it will appear that the incorporators were not without ambition, and followed Emerson's injunction to "hitch your wagon to a star." They felt, at all events, that the seed which they were sowing was a good one, and that, like the mustard seed of old, it might sometime grow to vast proportions.

It was on March 20, 1914, in the Labor Temple, Toronto, immediately after the organization meeting of the U.F.O. that the first shareholders' meeting of the United Farmers Co-operative Company took place, at which a permanent board of thirteen directors was 
appointed. From among these directors W. C.' Good was elected President and Anson Groh, Vice-President. J. J. Morrison was chosen Secretary-Treasurer.

Up to this time no prospectus had been issued. It became necessary now, however, to go out to solicit stock and, therefore, a prospectus had to be prepared, signed by all the directors, and filed with the Provincial Secretary. This was undertaken at the next directors' meeting, held in the Carls-Rite Hotel on April 13th. On this . occasion E. C. Drury, the first President of the U.F.O., made application for and was allotted one share of stock in the Co-operative Company, and was then and there elected a director, one of the provisional directors retiring. At the next meeting, on April 25th, the prospectus was signed, and interviews granted to several business men who wished to link up with the organized farmers. At the next meeting, on June 30th, the directors inspected the Toronto Civic Abattoir, then nearing completion, on the invitation of the City Council. By this time a number of applications for stock (mostly from farmers' Clubs and subordinate Granges) had been received, and stock was allotted in conformity therewith. It was also decided to. open an office in Toronto, and to seek an opportunity of advertising the Co-operative 
Company at the Canadian National Exhibition.

During the spring of 1914 the Secretary, Mr. Morrison, had operated as best he could from his home on the farm in Wellington County, but on July 22 nd he secured temporary accommodation in the office of the Weekly Sun, Toronto, where he stayed until September.

Meanwhile the Great War had broken out, and the future looked very dark and uncertain. Writing of this period in the Christmas number of the "Canadian Countryman" for 1919, W. C. Good, then President of the United Farmers Co-operative Company, says, "In September a room was rented at 100 Church Street-really most dilapidated quarters with the plaster off the wall and without heat. It was the only thing within our means at that time, however, and we were not ashamed of it, believing it more honorable to wear a threadbare coat that we had paid for, than broadcloth for which we could not pay. This was the first office the joint organization had, and for a time not even a stenographer was possible. It being necessary for $\mathrm{Mr}$. Morrison to take the field in connection with the organization work, Mr. C. E. Birkett was engaged as chief and only office man, and rendered devoted service for several months, turning his hand to anything that needed to be donetypewriting, bookkeeping and correspondence. 
During the fall of 1914 it was difficult to keep up courage and to keep the venture from collapsing. The War had distracted everyone's attention. Farmers were busy and did not give the new movement much support. And meanwhile we had undertaken to open up an office and carry on. Personal sacrifice on the part of those responsible was the only thing that tided us over that period. I remember once, in October, leaving my roots and going to Toronto for three or four days to help out, while Messrs. Morrison and Birkett were almost living on bread and water. But we hung on, and gradually the tide turned in our favor. The next winter, I devoted my time to the extension of the Company's activities and to propaganda work. Others were similarly active. And when winter came on farmers had more time to consider the matter and we managed to keep our heads above water."

This was the period of seed sowing, when progress was slow, and it was hard to keep up courage. The business grew steadily if slowly, however, while local organizations of farmers in increasing numbers became shareholders, There were as yet comparatively few individual shareholders.

During the fall of 1914 , the following circular 
was gotten out and distributed widely throughout the Province:-

\section{To THE FARMers OF ONTARIo}

"You may perhaps know something of the present state of happy prosperity in the little kingdom of Denmark, the land where there are few rich men and no poor; and where the average of wealth and contentment is probably higher than anywhere else in the world. Fifty years ago Denmark had just come out of a disastrous war with Germany, loaded with debt, and oppressed with a heavy war indemnity. Her soil was of the poorest, her climate not the best, and yet, in spite of these handicaps, she has achieved the present happy conditions. It has all been brought about through the application of one principle-Co-Operation.

- "What co-operation has done for the farmers of Denmark it can do for the farmers of Ontario, and more. We have already begun a movement to bring this about. We want your help to complete it. We have formed the United Farmers Co-operative Company to bring producer and consumer closer together for their mutual benefit. We have already established many desirable connections. All we want is the whole-hearted support of the Ontario farmers. Will you help us to get it?

"Associated with the Company is the organiz- 
ation known as the United Farmers of Ontario. This is open to any Club, Grange or other local organization of farmers. It is designed to * federate all the local farm organizations in the Province of Ontario, and to educate along co-operative and other lines, for co-operation is a thing of education; it does not grow in a day. It is needless to say that the United Farmers of * Ontario is strictly non-partisan.

"We want your help in this great project. If you are a member of a Grange or Farmers' Club, see to it that your club affiliates with the United Farmers of Ontario. If there is no such organization in your neighborhood organize one. For full particulars address the Secretary of the United Farmers of Ontario, Mr. J. J. Morrison, 100 Church St., Toronto.

"The movement needs your help. You need the benefit of co-operation with your neighbors. Let us all get together and accomplish this great thing. We can do it. Get busy.

"The Officers and Directors of the United Farmers of Ontario.

E. C. DruRy, President."

The first annual meeting of shareholders of the United Farmers Co-operative Company was held at the Carls-Rite Hotel, with about seventy-five present, on February 24th, 1915. The Directors' Report, after reciting what had 
been done during the first year's existence, continues as follows:-

"We would direct your attention to the statement attached to the Balance Sheet, in which is seen the development of business in our Supply Department during the four months October 1st, 1914, to February 1st, 1915. During this period the volume of business has increased over five-fold. The net revenue from commissions has overtaken our current expenses, and we have a substantial profit on our January turn-over. The expense of doing business has decreased from over three per cent. in October to less than one per cent. in January, notwithstanding considerable of our expense is chargeable to organization work. And, when we include with this the reductions in prices we have obtained under our trade agreements, we have much reason to be thankful."

The following excerpts are also of interest:"......... up to date we have not been able to give sufficient attention to the selling end of our business

the major part of the paid up capital stock has gone for organization work ........ no commissions have been paid on any subscriptions of stock ..... up to date we have thirty-three individual shareholders and fiftyeight corporate shareholders . . . . . . " 
The turnover for that part of 1914, during. which the United Farmers Co-operative Company was definitely in business was some $\$ 33,000$; but this was exceeded by the turnover of January, 1915, alone. After this, however, the business generally fell off until it reached the low level of a little over $\$ 5,000$ for September. From that point it again began to increase, totalling some $\$ 226,000$ for the full year 1915 , on which a net profit of some $\$ 1,800$ was made.

The President, Mr. W. C. Good, in his report for 1914 dealt with some of the difficulties and obstacles which the Company had to face and* overcome. There were, first, "The difficulty of getting trained men for positions of responsibility," second, "The danger of sacrificing cooperative principles,"thirdly, "The individualism . of the average farmer," fourthly, "The problem . of internal business organization," and lastly, "The problems of local financing and ware-" housing." The concluding sentences of his report may be quoted verbatim.

"It matters little what you and I get out of this movement; but it matters a great deal what we put into it. We are here to-day and gone to-morrow, but our work will remain, for good or evil, so long as time shall last. Let us there-fore, try to realize that we are engaged in a 
great moral crusade, which has as its object the establishment of justice in industry and * commerce. Thus directed, our efforts cannot fail, because they are in accord with the Ultimate and the Real. That this should be our attitude, our outlook, and our confidence, in this our first annual meeting, is my sincere desire and earnest hope."

After this meeting the Vice-President, Mr. A. Groh, was elected President and General Manager, and Mr. A. A. Powers, Vice-President, while Messrs. Drury, Good and Gurney, together with the President and Vice-President, were appointed an Executive Committee. Six Directors' meetings were held during the year, and a considerable number of new Farmers' Clubs became shareholders. The office was moved, also, in the fall, to much more agreeable quarters at 110 Church Street.

The Directors' Report for 1915 noted some new developments, among which the following are worthy of mention: The publication of a monthly trade bulletin, with a weekly supplement appearing in the Sun; further study of the marketing of live stock, fruit, butter, eggs, etc., and a closer connection with manufacturers. Only 142 shares of stock had been sold, however, so much was yet to be done in this direction.

Mr. Groh's message as President may be 
summed up in the concluding words of his report: "Altogether, keep cool, hold steady, and pull strong."

The annual shareholders' meeting, at which the above reports were presented, was held in St. James Parish Hall, Church Street, on February 2,1916 , and many varied aspects of the farmers' commercial business were there discussed. A motion was carried to separate the offices of President and General Manager, in conformity with which Mr. John Pritchard was elected President by the Board on February 3rd, Mr. Groh still retaining the position of General Manager.

An interesting supplementary statement was presented to the shareholders at the above mentioned meeting, showing the position of affairs on February 1st, 1916, part of which is here published.

The United Farmers Co-Operative Company's Statement

Shares Sold ...................... 183

Amount paid on same..............

Amount unpaid on same.............

$\$ 3,075.00$

$1,500.00$

Representing...........

$\$ 4,575.00$

Shares unsold ..................217

Shares spoken for not signed up........ 22

Representing...........

$\$ 5,425.00$ 
Shares held by individuals $\ldots \ldots \ldots \ldots \ldots \ldots \ldots .66$

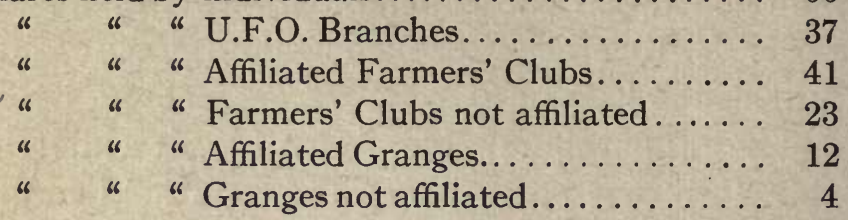

Number of U.F.O. branches................ 77

" " " " not holding stock..... 40

Total number of Farmers' Clubs.............. 264

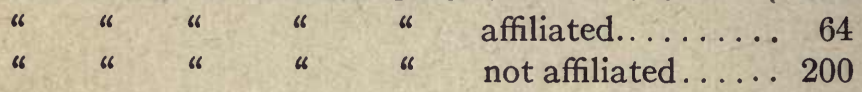

Number of U.F.O. branches that are dormant..... 3

Number of Affiliated Farmers' Clubs that are dormant 9

Number of Affiliated Granges that are dormant... 2

The lapsing of unincorporated local organizations, holding stock, mentioned in the statement just quoted, created a strange situation. When the United Farmers Co-operative Company was first organized the question of stock holding by unincorporated farmers' clubs was an embarrassing one, and the solution arrived at was that each local association should appoint one of its members or officers to act as trustee for it. This solution was not wholly satisfactory, however, while the situation became greatly more difficult in case the local association lapsed. To whom could dividends be paid? Difficulties of this sort probably had some influence in bringing about a change of policy as to shareholding with- 


\section{THE U.F. CO-OPERATIVE CO. 81}

in the next two years, which will be noted in due course.

In April, 1916, the United Farmers Co-operative Company affiliated with the Canadian Council of Agriculture, the directors personally guaranteeing the affiliation fee; and again the question of propaganda received earnest attention. About this time certain difficulties developed in the office which finally led to the resignation of the General Manager on July 10th. Mr. C. W. Gurney, one of the directors, was appointed Manager pro tem. In the fall Mr. L. H. Blatchford was appointed Assistant Manager.

During the summer of 1916 the directors had under consideration the changing of the system of stock holding by clubs to that of stock holding by individuals. Difficulties already mentioned favored consideration of this matter. It was also judged necessary to increase the capital stock, and it was thought that more stock could be got if it was subscribed by individuals than if it was subscribed by local organizations, particularly since the latter did not of ten take more than one share. As yet most of the stock holding was by clubs: witness the fact that as late as January 17th, 1917, allotment was made to fourteen clubs and eight individuals. 
The next shareholders' meeting was held on March 1st, 1917, at which the number of directors was reduced from thirteen to nine, and steps were taken to increase the capitalization from $\$ 10,000$ to $\$ 250,000$. A new system of electing directors was tried out at this meeting, with nominating and electing ballots and the transferable vote. It was measurably successful, but was subsequently modified by restoring open nominations and the use of successive ballots instead of the transferable vote.

The address of Mr. Pritchard, the President, dealt largely with the general effects of the War upon agriculture, called attention to the advisability of departmentalizing the Company's work, and stated that arrangements had been already established with a firm at the Union Stock Yards for the handling of live stock: For the ensuing year Mr. B. C. Tucker was elected President in Mr. Pritchard's place.

Another prospectus had now to be gotten out, and in March this was taken in hand. At the same time it was resolved to go after the individual farmer as a shareholder, instead of the Farmers' Club. The live stock end of the business, not being satisfactory, also received a good deal of attention, while negotiations, which were to last for months, were begun with T. J. Medland \& Company, grocers. Arising 
out of these negotiations the office was moved to the Medland Building on King Street, where it still continues. The first rental paid there was only $\$ 25.00$ per month.

The negotiations with T. J. Medland \& Company contemplated the taking over of the Medland business on King Street, but finally fell through on September 18 th, so that nothing further need here be said about it. It is worthy of note, however, that on the same date R. W. E. Burnaby, who subsequently figured so largely in the Company's affairs, applied for and was allotted one share of stock. It is noteworthy, too, that Mr. T. A. Crerar, who had been elected an honorary director, was in attendance at a number of directors' meetings for several years, a fact that indicates the close relationship between the farmers' movement in Western Canada and that in Ontario. From time to time, also, most of the Western leaders have appeared and spoken at the annual gatherings in the East.

In June, 1917, a communication which marked * the beginning of an important controversy was received from the Brant Farmers' Co-operative Society, in which, after reciting a resolution passed by the Board of Directors of the latter Society, it was urged "that co-operative societies exist for the express purpose, in the interests of the people, of eliminating competition, and the 
inevitable waste of energy and resources occasioned thereby. This Society has been organized to provide a local service which the needs of the farmers of the county demand; a service it is impossible to supply fully from a central point sixty-five miles away. The fact of the existence of such local service must create a demand considerably in excess of what can be expected from a provincial organization without local facilities. If, therefore, the provincial and local societies work in sympathy and co-operation, and in a spirit of loyalty to each other, the trade accruing to both must be much greater than would be possible if such local organization did not exist.

"It is essential to the promotion of co-operative business in this county that the two organizations should not compete with each other in seeking to satisfy the requirements of local farmers, for such a policy would, as cooperative experience elsewhere teaches, impair the efficiency, value and success of both, and actually create trade conditions, that it is the purpose of the movement to destroy. The Board of this Society is of the opinion, therefore, that in consideration of its desire to utilize the facilities of your Company as a wholesale organization, there should be an understanding that the United Farmers Co-operative Company will not compete with this Society within its 
sphere of business operations. It is further felt that a provincial organization such as yours should, as the local agricultural co-operative movement develops in Ontario, function as a wholesale for the local organizations, and for which its central location and circumstances are better adapted."

The matter of the above communication was laid before the Board of the United Farmers Co-operative Company and brought forth considerable discussion. However, no decision was reached in regard to the general question raised on the relationship which should exist between local co-operative societies and the Provincial Company. It will be recalled that the original, purpose of the United Farmers Co-operative Company was to serve the commercial interests of the various local farmers' organizations affiliated in the U.F.O., and to consolidate and harmonize their work. It will be recalled, too, that at first most of the shareholders in the United Farmers Co-operative Company were Farmers' Clubs and similar local organizations, but that gradually individuals replaced organizations as shareholders. In fact, in the spring of 1917, a general decision was reached, for reasons already outlined, to go after the individual farmers instead of the local organizations. There $*$ emerges, therefore, at this point in the history 
of the United Farmers Co-operative Company a fairly distinct difference of opinion:-in the first place the view which had prevailed during the earlier years of the Company's existence, and assumed in the communication from the Brant Farmers Co-operative Society, and in the second place that towards which the majority of the Board of Directors of the United Farmers Cooperative Company were at this point inclining, but which had not been yet clearly decided upon as a general policy. From time to time during the balance of 1917 this problem received consideration, but no definite decision was reached. Meanwhile the stock was being taken up fairly fast. Fifty-three shares were allotted on August 10 th and one hundred and eighty shares on November 23rd, when Mr. Burnaby, who had been selling stock with success, was present at the the Board meeting.

On October 5th, in this year Mr. C. W. Gurney resigned as Manager and Mr. L. H. Blatchford was promoted to take his place.

The next shareholders meeting took place on December 21 st in the same year, in accordance with a decision to hold the U.F.O. convention in December instead of later on in the winter. About two hundred shareholders were present, and, as the new prospectus was ready, an enthusiastic campaign of stock selling, led by 
Mr. Burnaby, took place at the meeting. Mr. Burnaby was elected a Director at the same meeting, and immediately afterwards President of the Company.

As has been already mentioned the turnover for 1915 was approximately $\$ 226,000$ with a net profit of some $\$ 1,800$. The turnover for 1916 was somewhat over $\$ 400,000$, with profits of about $\$ 4,000$. Owing to the change of date of the annual meeting, the statement for 1917 covers only the ten months ending October 31 st, 1917, during which the turnover had grown to over $\$ 900,000$ with profits of some $\$ 3,600$.

Early in 1918 reports from a cheese committee and from a live stock committee are to be noted. The latter of these received then, and continued to receive, much attention, until finally, during the next winter, a live stock branch was opened. at the Union Stock Yards, Toronto.

Attention was now directed towards securing . a "big man" for Manager, and in June Mr. Blatchford resigned and Mr. L. M. Powell was engaged. The selling of stock was proceeding apace and the business growing fast. Early in . the following year Mr. Powell left the Company's employ and about a month later Mr. T. P. Loblaw was engaged as Manager.

The year 1919 was marked by very rapid . expansion in many lines, and by a great increase 
in the capital stock, the latter being now taken almost exclusively by individuals. The turnover jumped from a million and three quarters in 1918 to eight and a half millions, most of which was due to the newly established Live Stock Department. Profits, too, were nearly $\$ 20,000$, but as over $\$ 21,000$ of these were made in the Live Stock Department alone the other departments together showed a slight loss.

During this year the business of the Company was divided into three departments, Live Stock, Commission and Co-operative Trading. Under the latter of these departments a number of branch stores or warehouses were established, stock for which was subscribed by those in the particular districts concerned. The lack of local business facilities had always been a great handicap; a condition that was especially felt at this time, when unusual effort was being made to expand the Company's business. Two ways of providing these local facilities were possible. One was by linking up, and using, local co-operative societies then in existence, and encouraging the formation of others like them; the second was by establishing branches of the Central Company, the stock being all subscribed (by individuals) in the United Farmers Co-operative Company, the latter establishing and operating the branches. Mr. Loblaw, the new manager, 
whose experience had been with chain stores, preferred the latter plan, which was endorsed by the Board of Directors and forthwith put into effect.

Inasmuch as a number of the Branch Stores, which were then being established, were located in towns, the question arose next as to the admission of townspeople, a problem which was finally solved by issuing "Participation Certificates" to urban residents; which certificates conferred the privilege of trading but not of voting. Special by-laws, providing for this, were submitted and passed at the next shareholders' meeting, held in Massey Hall, December 16th, 1919.

Meanwhile, in October, the U.F.O. had achiev-8 ed unexpected and spectacular political success, and two directors of the United Farmers Cooperative Company (Messrs. Drury and Doherty) were respectively Premier and Minister of Agriculture for Ontario. The annual shareholders' meeting for 1919 was, therefore, one of peculiar interest and importance. The attendance was greatly in excess of anything hitherto attained, and enthusiasm ran high.

Criticism, however, was not wholly lacking. " Mr. W. C. Good, the first President of the United Farmers Co-operative Company, and a Director until the winter of 1917-1918, publicly called in question the whole recent policy of the 
Company in respect to the establishment, financing and control of branch stores, the control of the central Company under conditions then existing - that is, with a multitude of individual shareholders, - and generally argued for a return to the constitution as at first designed. The natural evolution of the Farmers' club on the commercial side was, he said, towards the formation of local co-operative societies, with subscribed capital, warehouse facilities, and a paid staff. Such co-operative societies should, therefore, he thought, form the units of the United Farmers Co-operative Company, just as various farmers' clubs constituted, financed, and - controlled the U.F.O. Such a return to the original idea would, he said, solve two serious problems. In the first place it would leave the management of local retail activities in the hands of local societies, which experience had shown to - be the only safe plan; and in the second place it would form a natural basis for representation by delegates at shareholders' meetings. The number of shareholders was then over 10,000, and it was manifestly impossible to hold a shareholders' meeting at which a majority were present. Some system of representation by delegates had become imperative, and the adoption of the policy of corporate instead of individual shareholders provided the basis for such a 
system. There were practical difficulties in the way, but these, he thought, could be overcome if the general line of action were adopted.

Time for fully discussing this matter was lacking at the shareholders' meeting, so the question was referred to the incoming Board of Directors to report upon at the next annual meeting. Mr. Good, also, was elected to the Board, to give expression to his views upon the matter under consideration. Two other changes in the Board may be noted at this time. Mr. Drury and Mr. Doherty, as members of the Ontario Government, withdrew from nomination. Vice-President A. A. Powers, was elected President for 1920 .

During the year 1920 the business of the Unit- ed Farmers Co-operative Company continued to expand rapidly. The Montreal Live Stock * Branch was established early in the year, and in the spring the Company purchased the Toronto Creamery. An Egg and Poultry Department. was also created under the management of Mr. R. H. Ashton, formerly manager of the Dundas (County) Co-operative Association. Attention was directed, also, to the seed business, and later in the year a seed cleaning department was established with $\mathrm{H}$. W. LeMay in charge. A grant of $\$ 200$ was made to the United Dairymen Co-operative Limited which had been 
recently incorporated as a result of the work of the Cheese Committee. A fruit department was also inaugurated under the supervision of Messrs. Lick and Craise, two of the directors. - A subsidiary wholesale department was incorporated separately, under the name of "General Wholesalers Limited," and the authorized capital was again increased;--from $\$ 250,000$ to $\$ 1,000$,000. A province-wide stock selling campaign was put on in June, under the management of Mr. Burnaby, and by the end of the year the million dollars had been oversubscribed. A mill was leased at Smiths Falls, and the branch stores increased in number from ten to thirty. The Live Stock business grew to about twelve millions, while the total turnover for the year was nearly twenty millions.

It is, perhaps, not to be wondered at that such spectacular development should render the Board of Directors indisposed to welcome criticism and suggested changes of constitution. At all events the representations made by $\mathrm{Mr}$. Good at the shareholders' meeting and subsequently urged upon the Board, produced no immediate results.

It was not all clear'sailing, however. On May 31st Mr. Loblaw resigned as manager, which resignation took effect the middle of July. For the rest of the year the President, 
Mr. Powers, occupied the position of Acting Manager during which negotiations for another general manager went on. Finally Mr. H. B. Clemes, who had had long and extensive experience with Gunn's Limited, was chosen, and Mr. Clemes took charge after the annual meeting.

Frequent changes of management were not the only difficulties which the United Farmers Co-operative Company had to face. There. was the perennial difficulty of finding and keeping good men in the various departments. Bookkeeping difficulties were also encountered, not unnatural in a business whose growth had been as rapid as was that of the United Farmers Co-operative Company; and a special auditor was appointed by the directors during the summer of 1920. The work then begun has been continued, so that at the time of writing it is announced that the accounting is entirely up-todate and accurate. If the position thus gained is maintained one great danger will be effectually guarded against, and it is to be hoped that the management will leave nothing undone to maintain the present very satisfactory situation in this respect.

Inasmuch as no decision had been reached by the Board of Directors in regard to the change of constitution recommended by $\mathrm{Mr}$. Good, the 


\section{THE STORY OF THE U.F.O.}

former considered at their meeting, in September, the propriety of submitting the whole matter to the shareholders in advance of the annual meeting, so that the question might receive more widespread discussion on the part of Club members. The majority of the Board, however, resolved "that no published report on this matter be handed out to the shareholders prior to the annual meeting." This decision was arrived at as the result of careful consideration given to a lengthy memorandum, in which detailed reasons were advanced in support of suggestions for a change of constitution and general policy. The matter was left in this shape until the shareholders' meeting on December 14th, 1920, when an amendment to the constitution was brought forward by Mr. Burnaby, providing for such reorganization of the Company as would establish local groups of shareholders, each of which would be represented by delegates at general shareholders' meetings. Inasmuch as the number of shareholders exceeded 20,000 by the end of 1920 , the necessity for some such change was patent. The general principle of the contemplated change was readily accepted.

- A question still to be faced, however, is that this kind of reorganization does not necessarily provide any means whereby the many independent local co-operative societies which are operating 
in Ontario can be linked up with the United Farmers Co-operative Company; nor does it . remove all the dangers of central management of localized activities. In North America a large * company, centrally managed, seems to carry a stronger appeal than does a federation of local societies. Thus the majority of the shareholders present, after some discussion, favored Mr. Burnaby's motion, so that the task of working out the details of reorganization in conformity with the principle of representation is left with the 1921 Board of Directors of the United Farmers Co-operative Company. Some concrete scheme will doubtless be submitted to the next shareholders' meeting as a result of this decision.

Another interesting aspect of the history of the commercial side of the farmers' movement in Ontario may be dealt with briefly in conclusion, From the outset, and increasingly as the organization grew in numbers and prestige, the Board of Directors was beseiged by people of all kinds, advocating a multitude of "good things" - of a manufacturing or commercial character. Agencies for handling all manner of commodities, milling and elevator propositions, timber limits, fence companies, and what not; all these were. attractively presented with recommendations to "dip in," or "take hold". For the most part 
the Directors have exercised most commendable caution in dealing with all these perplexing matters, and have confined their attention mainly to those activities which were unquestionable - the marketing of the products of the farm and the purchase of supplies. It would be time enough to consider manufacturing and other enterprises when the Company had become firmly established on the basis already chosen. Generally speaking, therefore, all such questions have been turned down or at least postponed.

Of recent activities little need be said. The opening of branch stores is being held in check until that department is further tested out. Very necessary attention has been given to the accounting, and efforts are being made to perfect the service in lines already in operation rather than to start new ones. The present is a most difficult time for all commercial undertakings and one would not be surprised if during the next few years, the United Farmers Cooperative Company, in common with all business, should pass through rather trying times. Let us hope that it may finally take its place as a permanently useful instrument in the hands of Ontario farmers for the building up of the great industry of Agriculture and for the making of a better Canada. 


\section{CHAPTER IV}

\section{THE FARMERS' PUBLISHING COMPANY}

The Farmers' Publishing Company, like the other institutions of Ontario's organized agriculture, was the outcome of long-ripening conditions. For many years farmers had felt that their interests were being inadequately treated in the columns of the press. As has been mentioned in a previous chapter, almost from the beginning of the U.F.O. there had been talk of establishing an official paper, but year after year went on during which committees were appointed, without much visible progress being made. Something was required to crystallize into action the widespread yet hesitating inclinations of the farmers. The occasion which precipitated such action was the pilgrimage of Ontario farmers, to Ottawa, in May, 1918, to protest against a violation of a solemn undertaking by the government of the day, largely on the strength of which it had been returned to power.

The proceedings of that memorable day, and the position taken generally by the organized farmers, were so inadequately reported in the 
press, and the views on public affairs of a most important section of the nation were so generally misrepresented, that a demand arose for a farmers' own press to reflect their relation, not only to their own, the fundamental industry of the state, but to public questions generally.

The necessity for a newspaper to speak for the United Farmers of Ontario had often been canvassed, but nothing tangible could be accomplished until after the need for something of the kind had been dramatically demonstrated at Ottawa.

This necessity became so apparent to the leaders of the movement after the Ottawa rebuff, and was so widely discussed in the country, that when further meetings of the general body were called in Toronto, early in June, steps were taken to bring the matter before those assembled. The urgency of action was further made clear, through a public threat from police headquarters at Toronto that the farmers might be refused the right to convene in the capital city of their native province.

In Massey Hall, therefore, on June 9th, the question of financing a U.F.O. newspaper was brought before a large meeting, the sense of which was strongly in favor of such an undertaking being launched. There had not been opportunity for a definite plan to be worked out; 
but subscriptions were invited from the floor for twenty-five dollar shares. Promises amounting to fifteen thousand dollars were forthcoming, and the executive was instructed to take the necessary steps to implement the meeting's desire.

A Board of Trustees of the funds was appointed, consisting of Messrs. J. J. Morrison, G. A. Brodie of Newmarket, J. N. Kernighan of Goderich, A. A. Powers of Orono, and Col. J. Z. Frazer of Burford. Of this body Col. Frazer was appointed chairman and $\mathrm{Mr}$. Morrison, Secretary-Treasurer.

Perhaps the most remarkable feature of the demand for a farmers' organ was the persistently expressed aspiration for a daily newspaper. Some of the most enthusiastic supporters of the movement were sanguine enough to believe that a million dollars could easily be raised to finance the venture, and thus put it at once in a position to compete against powerful organs that had been circulating throughout the province for more than three quarters of a century.

It will help the reader to understand this persistent demand for a daily, if he bears in mind that the War was the all-absorbing centre of interest, and that the operation of the Military Service Act had brought home to many a rural community in a new way the sacrifices demanded by war. The farmer, who ordinarily 
had respected the current dailies, and who had placed much confidence in the promises of governments, now found himself completely disillusioned, and in his despair he grasped eagerly at any proposition which offered relief from his intolerable situation, by restoring a source of information in which he could place his trust.

The trustees, however, first considered the much less ambitious possibility of acquiring an existing weekly paper that had championed the farmers' economic and political cause for about twenty years.

The Weekly Sun had been founded by Dr. Goldwin Smith, and, at his death, had passed into the ownership of a body of gentlemen who had willingly sacrificed certain of its prospects of revenue to their adhesion to an anti-high - protectionist policy. The paper had many warm friends among the organized farmers. It was thought that possibly it might be utilized as a base from which the ideal of a daily journal could be attained.

The proprietors expressed themselves as willing to dispose of their property; but after considerable negotiations the trustees felt that they could not meet the terms offered. Other proposals were made to the Trustees, including the offer of a second paper endeavoring to serve the 
rural population, and a suggestion for joining with another enterprise that was being promoted, with headquarters in Stratford. But on examination these could not be entertained, and the Trustees decided to test the feasibility of founding a daily newspaper.

In accordance with their authority, and sufficient of the promises made at the Massey Hall meeting having been implemented by the payment of cash for shares, the Trustees on September 6th incorporated The Farmers' Publishing Company, Limited, with an authorized capital of $\$ 500,000$, they themselves being constituted, in agreement with the custom usual in such affairs, the first directors. Mr. Kernighan was appointed managing director; and during the month of September the situation was more carefully prospected.

It was recognized that the general field was already well occupied by experienced men, both editorially and commercially; and that something off the usual line would have to be devised, in order to give the world its first daily newspaper devoted primarily to the advancement of farmers and their families. One of the most experienced journalists in Canada was engaged to report on the possibility of a body of farmers issuing a newspaper of their own that would compete with existing dailies. 
In the course of a few weeks the report was presented to the board of directors, and accepted as a basis on which to proceed. It very strongly recommended the founding of a daily paper, in contrast with the original conception of a weekly. Events, however, subsequently proved it necessary to proceed with the scheme of a weekly paper at first, but as a daily paper is still the ultimate goal of the movement, it may be well to state here the considerations. which encourage the farmers to hope for their own daily at no very distant date.

There are approximately two hundred thousand farmers in Ontario. A careful survey led to the conclusion that more than half of them were receiving at least one newspaper daily. - To the forty-six daily journals then published in Ontario, therefore, the farmers were subscribers - for one hundred thousand copies. That was equal to five daily papers of a circulation of twenty thousand copies each. Newspapers in cities of the third class, with a circulation of from six to eight thousand, with their attendant printing business, were known to be highly flourishing.

All the daily newspapers, it was further pointed out, are written for the cities and towns, and only incidentally for the rural sections of the province. In any of them, all news of direct 
interest to the rural population could be given in much less space than was being taken to carry city news, and purely city advertising. It would not be necessary to equal the size of the city papers, seeing that at least one-third of the contents of the city dailies most widely circulating in Ontario was really waste matter for rural subscribers.

The rural mail delivery brought newspapers to the farms at trifling expense, so that in the matter of distribution the farmers' paper would be at once on a par with the greatest journals in the province. On the business side it was apparent. that, as every farmer buys more goods than the average city reader owing to his calling necessitating continual purchases from manufacturers and other large advertisers, the farmers' constituency as a buying community was on a higher level than the average community to which existing journals appealed. A journal written for a constituency of two hundred thousand families not now furnished with a daily paper devoted to their requirements, and conducted with as much or more ability than was applied to its competitors, it was felt, would have every prospect of substantial success.

The great question, therefore, was one of finance; and here also was the great difficulty. It must be remembered that, up to this time, 
the utmost the allied farmers of Ontario had done in the way of collective financing was in starting the United Farmers Co-operative Company. But its total raised capital was then only twenty-five thousand dollars, and our people had not attained the confidence in their own commercial capacity which they have since developed.

The directors, however, went resolutely to work. Mr. Kernighan found he could not devote to the Publishing Company all the time required, and the management was taken over by Mr. Powers. Representative men in each constituency were invited to supervise the obtaining of subscriptions for shares which were fixed at twenty-five dollars each. Meetings were held, at most of which excellent responses were received to the call for funds. But the enterprise, as then entertained, i.e. a daily, proved to be heavier than was anticipated. Some of the wisest leaders of the movement also felt strongly that it would, after all, be better to walk before they tried to run, and to see whether The Weekly Sun could be acquired. This feeling was the more natural, in view of the Sun's long and honorable service to the common cause. It would be anomalous to compete against it.

The whole matter was submitted to the annual convention in December, with the result that 
negotiations with the proprietors of the Sun were resumed, and, in April of the new year that established and faithful paper became the property of the Farmers' Publishing Company.

At this point it seems appropriate to give a brief sketch of the history of the paper which under various names has continued to champion the cause of the farmers ever since it was founded.

The Weekly Sun owed its origin to the late. George Wrigley and the Patrons of Industry. When the Patron Organization had attained some proportions, the need of a medium through which the leaders could reach the rank and file, and by means of which the members could communicate with one another was keenly felt, and out of this need the Canada Farmers' Sun. was born, and became the official organ of the Patrons.

At the beginning, the Canada Farmers' Sun was published in London, but as Toronto was nearer the centre of the province and became the meeting place of the Central Organization, it was soon found desirable to change the place of publication to Toronto. Just at this period the Patron Movement was at its height and the Sun enjoyed a circulation of well over twenty thousand. But with the rapid decline of the Patrons, the circulation of their paper fell 
rapidly, too, until in 1896 there were only some four thousand subscribers.

That was the most discouraging stage ever reached in the modern history of Ontario Agriculture. An organization from which much had been expected was no more; the organ of the Patrons barely continued to exist and its demise appeared to be only a question of time. The fiery enthusiasm of the previous period had given place to a feeling of "What's the use?" Mutual suspicions fostered by old line politicians, had taken the place of mutual trust. It seemed as if farm unity was to be a thing of the past and as if farmers were to become and remain for all time an unorganized, voiceless mass.

* It was at this time that the ablest, one of the most completely unselfish, one of the best friends Ontario farmers ever had, came upon the scene in the person of Goldwin Smith. "Came upon the scene" is, however, hardly the phrase that fits the occasion. The sage of the Grange, from the time of his arrival in Canada a quarter of a century before, had been interested in the - agricultural life of his adopted Province. With the passing years he became more and more convinced that the hope of democracy in Ontario lay along the concession lines. No one felt the position in which the rural people found themselves in the late nineties more keenly than he 
did. None had a clearer apprehension of the consequence that must follow upon a continuation of that position, not only for agriculture, but for Ontario as a whole. And Goldwin Smith determined to do whatsoever he might to prevent the existing condition from continuing and even growing worse. With this object in view he purchased the journal that had served as a mouthpiece for organized agriculture. $\mathrm{He}$ was absolutely free of any personal object or personal ambition. He had outlived the animosities arising out of controversies inseparable from active participation in the public affairs of two continents, and more particularly of three countries. Having already passed the Psalmist's limit of three score and ten years he had neither hope nor desire of public position or preferment for himself. His position in the world of letters was secure. His one desire, his one aim, was to assure the continuance of a journal by means of which the voice of rural Ontario might be heard in the councils of the Province and the Nation.

With the purchase of The Sun a company, under the name of The Sun Printing Company, with Caleb A. Mallory as President, and W. D. Gregory as Vice-President, was formed to manage it. The name of the journal was changed at the same time to The Weekly Sun. There were two 
' reasons for this change. The old name was a cumbrous affair, and it was believed that with Goldwin Smith as a regular contributor under the pen name of "A Bystander," the paper would make an appeal to urban as well as to rural Ontario. This latter belief, however, proved to - be not well founded. From the first the readers of The Weekly Sun, as had been the case with The Canada Farmers' Sun, were found almost exclusively among farmers. Despite the discouraging circumstances attendant upon the re-birth of the farmers' paper, circumstances arising out of the lassitude and discouragement following the Patrons' collapse and the general economic conditions at the end of a long period of depression, The Weekly Sun grew steadily in circulation and influence until its list of subscribers numbered between ten and twelve thousand.

Then arose two causes which resulted in a severe set-back, the Boer War and the beginning of an agitation which found its culmination in Provincial Prohibition. Goldwin Smith was a man of strong convictions and he never sidestepped an issue. A man of absolutely clean life, and temperate in all things, he conscientiously believed that the use or non-use of intoxicating liquor was a matter to be settled by the individual conscience rather than by legislation, and 
he preached what he believed. Since that. preaching was to a constituency which formed the backbone of the temperance crusade of the sixties and seventies, and of the Prohibition crusade of a later date, the effect could not be other than disastrous on the circulation of The Weekly Sun.

The course taken in the "Bystander" column, . which vigorously criticized the Boer War, was also unfortunate, so far as the immediate effects on circulation were concerned. But the ultimate result, even from the narrow standpoint of business success was beneficial. Men of opposite view at the time came to respect a man and a journal that had the moral courage to stand up for convictions sincerely and honestly held in the face of popular clamor. It is the belief of many that the stand taken by Goldwin Smith in the Boer War did more, in the end, to establish public confidence in The Weekly Sun than any other one thing in the history of the paper, and proof of the soundness of that view is found in the fact that in a few years lost circulation was fully regained. But the victory won entailed very heavy financial sacrifices. In establishing The Weekly Sun in the first place; and in carrying it through the period of trial referred to, Goldwin Smith spent first and last some thirty thousand dollars. That burden was 
borne for one purpose alone: to secure for agriculture a journal of its own. Had it not been for what Goldwin Smith did, the death of The Sun must soon have followed upon the death of the Patron organization. Only for the financial sacrifices made, the seed sown by the Grange, and later on nurtured by the Patrons, might not have flowered into the mighty Farmers' Organization of to-day. For what he did, whatever views may be held as to his stand on the question of Prohibition, the name of Goldwin Smith will ever be held in grateful remembrance by the farmers of Ontario.

It is no small satisfaction to know, too, that the reward, the only reward looked for, came before one of the greatest humanitarians of the age passed from the scene. Ere the eyes of Goldwin Smith closed for the last time, the paper that he had saved was on a sound financial basis. The journal that he had nurtured through adversity was in his thoughts to the end. The last words heard from his lips were, "Forward the Toronto Sun."

It was therefore a happy turn of events which led the United Farmers to acquire the paper which had so long been the friend of agriculture. Under their direction, and with a new name, it has continued to bring encouragement and instruction to thousands of rural homes. The 
phenomenal success of the Farmers' Movement * in Ontario is in no mean measure due to the influence of The Farmers' Sun. Through its * columns, democratic principles have been persistently advocated, and readers have been given an insight into economic conditions as presented from the rural viewpoint.

Through all this development a very curious relationship has existed between the parent organization and the owners of the paper. Who are the owners and by what means do they exercise the prerogative of ownership? As already noted, the scheme was first mooted and further promoted at meetings of the U.F.O. The initial committee was appointed by the U.F.O. But when the committee came to the point of taking definite action and had to appeal for funds there were two sources from which such monies might come. Either the scheme could be financed from the central treasury of the U.F.O., or it could be financed separately by individual men buying shares direct in a publishing company. Since the central treasury pos-sessed no more funds than were required for organization and educational purposes, the committee was forced to appeal to individual members, and thus the Farmers' Publishing Company was formed, and shares were offered at twentyfive dollars each. This, in a sense, leaves the 
Publishing Company quite independent of the U.F.O., since each has its own president and separate board of directors. The bond of connection rests in the fact that the shareholders of the company are in practically all cases members of the U.F.O. The success of the one is closely bound up with the success of the other, so that a circumstance in which the policy of the paper would run contrary to the policy of the U.F.O. could hardly arise.

It must not be supposed that the Publishing Company was formed and brought to its present state of prosperity without encountering serious obstacles and serious opposition. There is every reason to believe that in addition to the difficulties arising out of war conditions, designing men put forth a good deal of effort to block - the effort. For instance although the application for the charter of the Publishing Company was made on the fifth of August, 1918, the charter was not forthcoming until long after; and repeated calls, which were often ignored, had to be made before, finally, permission was - given. Then a further complication arose - through scarcity of newsprint. An organization of newspaper men, alleged to have been fostered and endorsed by the Government, set on foot a scheme to prevent the promotion of further newspapers in the field. Mr. Pringle, the paper 
controller, a man of broad and liberal mind, however, made it plain at the outset of the meeting of publishers held at Ottawa, that the Farmers' Publication was not to be considered a newspaper, and that on request from them they would receive their fair share of newsprint.

No account of the early activities of the Farmers' Publishing Company would be complete without some reference to a special edition of the paper issued in January, 1919. It should be borne in mind that not until the first of April of that year was The Weekly Sun acquired, and therefore no regular paper was published until after that date. Following the annual convention of 1918 the directors of the publishing Company thought it advisable to publish a special edition in which would be recorded, not only a full report of the convention, but also many other interesting facts concerning the movement. The material was compiled, the character of the edition decided upon, and all was proceeding merrily until the manager came to register the name of the paper. Then, to his surprise, he found that the name "The United Farmer" had been already copyrighted. Further inquiry brought out the story that an enterprising city editor, having heard of the intentions of the farmers, conceived the idea of copyrighting their title in his own name, and 
then selling the copyright to the organization at a highly remunerative figure. In good time his offer came to the Board of Directors, but as in the words of the Scottish poet "the best laid plans o' mice and men gang aft aglee," the stubborn directors simply ignored the offer and adopted the less expensive plan of choosing a different name.

Through such experiences, amusing and annoying, the Sun has continued to grow. When taken over, slightly more than two years ago, the circulation stood at twelve thousand; to-day it reaches more than forty thousand homes and is increasing its field daily. Not only is it growing in circulation but in subject matter it is continually adding to its store. What its future is to be rests largely with the farmers themselves. It is theirs to watch, to read, and to counsel. Under wise and broad minded management, it is destined to wield a mighty influence on the current of public events in Canada. 


\section{CHAPTER V}

\section{THE UNITED FARM WOMEN}

In the autumn of 1918 there went out to a number of representative farm women from the head office of the U.F.O. a communication inviting an answer to the following question, "What in your opinion will be the greatest benefit of the U.F.W.O. to the farm women of Ontario?". From the many answers received the following are selected as typical,- - "It will broaden and deepen their interests and help them to think for themselves," "It will give opportunity to develop individuality and natural gifts," "It will educate them along the line of what they ought to want and how to get it," and "It will bring farm women together in pleasant and profitable relationship." Such was the vision which inspired the women who became leaders in the movement. How far the vision has been realized we are now to inquire.

The history of the United Farm Women of Ontario is still very short. Three years only have passed since the inaugural meeting, years during which reaction from the stress of war activity has been most marked, and yet in 
spite of uncertainty and discouraging conditions - steady progress has been made. From the small nucleus of a dozen interested individual women the U.F.W.O. has now grown to one hundred and seventy-five clubs with a total membership of more than six thousand.

The project was first undertaken in the spring of 1918 , although for a long time such a step had been contemplated. Almost from the beginning. of the U.F.O. Mr. Morrison had been receiving letters inquiring if the farm women were not to be included in the organization as well as the men. As time went on the necessity of action became increasingly evident. During the progress of the War, women had been assuming an ever larger share of direct responsibility in - matters of State. The prospect of the Provincial franchise for women, with the promise of similar legislation at Ottawa, made it abundantly clear to all that the woman electorate would soon be a force to be reckoned with at the polls.

But it was not chiefly political reasons which induced one or two members of the U.F.O. executive to consider the advisability of inviting the active co-operation of the farm women.

- Probably in no occupation in the world is the association of men and women closer than on the farm. In the conduct of the household, the woman oversees, and in most cases, actually per- 
forms all those various duties vital to a self contained home. Out of doors she takes a share of . the responsibility also. Here her interests merge with those of the men, while in the isolation of the farm, for companionship the man and the woman constantly look to one another. Inside and outside the work is complementary, each in its own way essential to the success of the other.

Just so in the life of the clubs, each required its due share of consideration. The men had organized for the avowed purpose of improving the condition of agriculture. No part of agri- . culture was in more serious need of attention than the farm home, and no one saw more clearly how the home might be improved than the farm woman herself. To make her ideas articulate she must have a medium for discussion and expression, and since the medium already existed in the club, all that was necessary was to secure her attendance.

Furthermore, all community effort had shown that where women were taking an active part the men showed a much more livelý interest. One of the great problems confronting club, officers everywhere was to induce the men to come out to meetings. It was not so much that they were not interested as, that after a hard day's work, it was a real privation to leave a cosy fire and family at home, and go off alone to an uncomfort- 
able schoolhouse or hall for a meeting that was anything but attractive. Had it not been for their keen sense of the handicap from which agriculture suffered, and their conviction that something must be done, one wonders if they - could have persisted so long. Enthusiasm for the cause maintained them, but enthusiasm under adverse conditions sooner or later wanes, and in the active participation of farm women leaders saw hope of renewing and strengthening - the movement. Thus it came about that steps were taken to give woman her rightful place in the farmers' crusade.

c In the early summer of 1918, Mrs. Violet McNaughton, a pioneer leader in the women's organizations of Saskatchewan, was to represent her Province at a convention of the National Council of Women in Brantford. Mr. Morrison made use of the occasion of her passing through Toronto to gather together such farm women as he knew to be interested in the matter of organization, to confer with her. On the seventeenth of June, sixteen women and three men met in the parlor of the Elm Street Y.W.C.A. and listened to Mrs. McNaughton as she outlined the work done by the Women Grain Growers' Organizations of the West and pointed out those principles which they from experience had found to make for success. 
The sixteen women entered the room in the " $Y$ " as sixteen unorganized individuals; they left it an embryo association. Not only were they inspired by the message to appoint officers, but they drew up a provisional charter also. With Mrs. G. A. Brodie of Newmarket as Provisional President, and Miss Emma Griesbach of Collingwood as Secretary, those present were constituted a standing committee, and went forth determined by all means at their command to arouse interest and to spread information as to the aim and purpose of organizing, which in general terms might be stated as the strengthening of the U.F.O. The U.F.W.O. was now "off to a start."

But these devoted women had undertaken a large order. While they had the constant and sympathetic encouragement of Mr. Morrison, the U.F.O. as a whole was not yet seized of their importance, and consequently the support of the men was still largely passive. Interest had to be awakened. Perhaps one of the most seri- ous handicaps under which the women labored was lack of experience. In the palmy days of the Grange, women had been admitted to membership in that institution, and even one or two subordinate offices were allocated to women. Miss Hattie Robinson is known and remembered by many of the passing generation for her 
splendid work as Secretary of the Grange, a position which she still retains. But since that time there had been no independent farmers' organization with a woman's auxiliary, and if there were any of the old workers still available, they were not known to officers of the U.F.O. Undaunted however by lack of experience, the provisional executive went to work, and although visible results were slow in making an appearance a great deal of missionary work was done.

Encouragement was not lacking. In some localities the time was ripe for organization. One of the first to urge upon Mr. Morrison the advisability of forming a woman's section was Mrs. Henry Wilson of Georgetown. Mrs. Wilson was one of the sixteen women who met Mrs. McNaughton, and no sooner had she returned than she invited her neighbors to her

s home. Twenty-three ladies attended, and there and then on the eleventh of July was formed the Ashgrove U.F.W.O., the first club of its kind in the Province.

An amusing incident happened in connection - with the third meeting of this club which was - held in the Orange Hall at Milton. Shortly after the business of the evening began, a number of people from the town appeared outside the building and expressed a desire to come in to the 
meeting. The President and Secretary, with an * open copy of the constitution in hand, met them at the door, and read them the section stating that only those directly interested in agriculture were eligible for membership in the U.F.O. The suspicions, attendant on war, were then rife, and the intruders returned to town spreading the information that the farmers were holding meetings behind closed doors and were guilty of seditious utterances.

Realizing that the best headway could be made only by securing the enthusiastic co-operation of the men, the women laid careful plans for * storming the U.F.O. annual convention. Preliminary to appearing in session with the men, they held a session of their own in a room loaned by the University of Toronto. At this, their first general meeting, there were thirty women present, but only sixteen came as accredited delegates, while only three U.F.W.O. clubs had yet been formed in affiliation with Head Office. Several helpful papers were contributed pro- . voking earnest discussion, and as a result the U.F.W.O., after adopting the men's platform in full, decided upon drafting a supplementary platform of their own, the main tenets of which should be noted as follows:

1. Improvement of rural homes and schools. 
2. Removal of disabilities of rural women in qualifying for school trustees.

3. Special attention to our system of education.

4. Appointment of county police matrons.

5. Labor-saving devices for the home on the free list.

This being accomplished and the provisional officers having been elected as permanent officers for the ensuing year, the women repaired to Convocation Hall where the men were assembled.

There, so far as that first annual convention was concerned, probably the best work for the U.F.W.O. was accomplished. Their standing with the U.F.O. must be secured. At the evening session, December 18th, 1918, the twentyfive women occupied seats on the platform facing the fifteen hundred men delegates, and, in the words of the secretary, "No warmer reception, no more enthusiastic response could woman desire than that accorded by the U.F.O. to the * U.F.W.O. that night. It became clear on that occasion that the men and women of rural Ontario were engaged to secure the removal of oppressive burdens from agriculture, to raise the standard of living on the farms, to establish a just and representative government, and to gain a bigger, better, freer life all along the line." 
The evening was given over entirely to addresses by the ladies, chief among the speakers being Mrs. Brodie, Mrs. Laws, and Miss Griesbach. The president indulged in some. plain talk, in which she made abundantly clear the attitude and ambition of the women. "I think," said she, "that there is only one thing worse than a farm without a woman and that is a farm without a man. What we women want to do is to co-operate with you men in Municipal, Provincial, and Federal matters, the same as we co-operate in the home. We ask no favors; we do not want anything for ourselves that the men do not get, and we do not want the men to have anything that we cannot share in." And again,-- "Some of you men can look back to the time when all through the country everything was done by co-operation; there were bees for everything - men had logging bees, paring bees, . husking bees and wood-cutting bees, while the women had bees for quilting and all that. At that time there was a social life in Canada that we have lost, and we are very much poorer, but it is not altogether our fault that we have lost it. We have been robbed of it by unjust* economic laws, and the women want to join up with the men for better laws, more equal laws, and we want to work for your motto which we take for our motto, 'Equal opportunity for all, * 


\section{THE STORY OF THE U.F.O.}

special privileges for none'." So sincere and convincing were these words that nearly every man went home to his club to advocate linking up the women of his community in the movement.

A practical difficulty arose and was dealt with at this convention, and to understand the organization fully, mention must be made of it here. In many localities women were anxious to have a place in the life of the club, but were not willing to form a club of their own. What was to be done for them so that they might have some standing? It is significant that a bachelor director came forward with the suggestion - which solved the difficulty. A resolution was passed by the executive and approved by the convention which amended the constitution so as to allow women to become members of clubs on the same terms as men, wherever there was no separate U.F.W.O. This arrangement has worked most satisfactorily. It must be clearly understood, however, that the U.F.W.O. is not an association marked off from the U.F.O. Women who are members of the U.F.W.O. are at the same time members of the U.F.O., because there are no separate funds. The women's membership fees are paid to the treasurers of the U.F.O. clubs and through them transmitted to Head Office where the funds are common to men and women alike. 
Through the activities of the women great things were hoped for, and events have demonstrated that such hope was well grounded. As an illustration of what is being accomplished we can take the words of a leader in a woman's club in Western Ontario as she wrote to a friend:

"It was during the dark days of the War that we farm women banded ourselves together, forming one of the live clubs in that splendid Red Cross organization. Through our work in it, we caught a vision of what can be accomplished through co-operative effort. During the winter of 1919, when our overseas work came to an end, we felt a keen desire to continue in the way of service, and to give of our time and energy in making our community a better place to live in. Our husbands, who were already United Farmers', whispered to us that they wanted our help in their organization and so we formed a U.F.W.O. . . . . We meet twice a month.

"In making out our programme, which we have type-written or printed, we select topics which we know will be interesting and instructive. We have every woman in our club take some particular item each year, and by this means make every member feel that the success of the club depends as much on her as on any other member. By each doing her bit, whether it be great or small, we have all learned to take 
our share of responsibility, and now know that we are a living force in the community.

Whenever we meet together, every woman receives a cordial welcome. By words and messages of encouragement we seek to develop a real neighborly and co-operative spirit, greatly adding to our community life. At our meetings we have an opportunity to make friends, to forget ourselves in working for others, and to express our thoughts without embarrassment. No feature on our programme has proved more beneficial than the social half hour set apart at each meeting for the purpose of becoming better acquainted.

"We always have objectives to work for. It may be the supplying of good literature for our homes, it may be work for some charitable institution, it may be for our local schools by way of decorating or putting better equipment in them. Now we visit or send flowers to the sick, again we are assisting the school or agricultural fair, this time it will be a baby clinic, and by a fine effort in 1920 we established a rest room - of our own in town. For all these purposes we raise money through teas, concerts, garden parties, lectures and plays.

"Today, looking back and taking stock of what we have accomplished, we feel that our efforts have been more than repaid. We have 
learned to respect one another, to be loyal to one another, to set aside trivial annoyances, to be considerate of each other's opinions, and to give as well as take. Every year brings an. increase in our membership, proving that through our activities our women are awakening to the necessity of doing something for the improvement of rural conditions, and to the success that can be attained through co-operative effort."

By the time that the second annual convention was held in December, 1919, most encouraging progress had been made. In contrast with the three clubs reported in affiliation with Head Office at the meeting in December the year before, the secretary could now show a membership of about 2,000 grouped in seventy clubs. If anyone doubted the strength of their organization by this time, his doubts must have been dispelled through the splendid showing made by the woman delegates as they occupied seats on the platform of Massey Hall behind the newly elected farmer members of the Provincial Government on the evening of December the nineteenth.

Many excellent discussions took place at this convention, but the most vital to the movement was that which turned on the young people of the farms. The women were the first to see the importance of work amongst the young people 
and also were the first to take steps to enlist their interest. Mrs. Frank Webster of Cambray presented the case for the young people so effectively that she was appointed one of a committee to bring in a report on how best to form a young people's branch of the U.F.O. While, as convener of this committee, she was considering what to do, there came to her the report of a committee of Alberta women on the Young People's Department of their work. After studying it carefully, she wrote out a draft constitution adapted to conditions in Ontario which she submitted to Head Office for consideration, and at a directors' meeting of the U.F.O. held in March it was provisionally adopted.

Shortly before this Mrs. Webster was in Northern Ontario holding a series of meetings and amongst other places she visited Peniel. A large number of ladies and young people turned out to hear her, to whom she outlined the aims and operation of the proposed Young People's Movement. It appealed so strongly to all present that, although the draft constitution had not yet been adopted by the directors, they - determined forthwith to take action. Thus, at Peniel that evening in early March, 1920, the first United Farm Young People's Club was organized and has continued to do splendid work ever since. 
The next club followed soon at Cambray, Mrs. Webster's home locality. Writing of this club Mrs. Webster says:- "We are proud indeed of our Young People's Brass Band, which has been financed entirely by the club and has now commenced playing at lawn socials and picnics. The refining influence that good music carries with it is wholesome, and we hope that through such pastimes our young people will be better prepared for the sterner tests of life. The fact that boys and girls meet together, I believe, is a strong point in favor of the movement. When a leader is chosen from the senior organization, parents are quite satisfied that their children are in good keeping. My honest opinion is that if we who are older will only give our time to organizing the Junior Sections, and helping them in any way we can, we will accomplish a very great deal for the future of our movement and our country."

Or another lady writes thus:- "We never lose sight of our energetic young girls. We have a real live U.F.Y.P.O. club in our community, and the girls of that club form a girls' committee in our woman's club. Every month the girls provide their share of the programme. The enthusiasm, which we who are older gain from our girls keeps us young in spirit, and strong in 
determination to make our community a happy, wholesome place for them."

The work of organizing the young people went briskly forward until the annual convention in December, 1920, when the constitution was formally adopted. The constitution is almost identical with that of the U.F.O. and U.F.W.O., except in those sections relating to membership and voting privileges at conventions. To cover these clauses the following rules are provided:-

"Any five young people with the assistance of a U.F.O. or U.F.W.O. member in good standing may organize a Junior Section.

"That a member of the U.F.O. or U.F.W.O. be elected as leader of the Junior Section, whose duty it shall be to supervise the work of the Junior Section and to assist in planning programmes, debates, etc., to attend all meetings and assist in every way to make the work of the Junior Section of high educational value to each member, always bearing in mind that the raising of the standard of education in the whole community is of fundamental importance.

"That the annual membership fee shall be twenty-five cents, ten cents of which shall be sent to Central Office.

"Membership. Any unmarried person over thirteen years of age may become a member by giving his or her name to the Secretary- 
Treasurer, paying the annual membership fee of twenty-five cents and taking the following pledge before the other members of the club at a regular or special meeting:

"Pledge. 'I promise to be loyal to the. organization, and to follow its laws; I will strive to become a good citizen and uphold all that is good and noble in the life of the nation. I. promise to be trustworthy, to give honest service, pursue knowledge, glorify God, hold on to health and be happy.'

From what has been said thus far it will be seen that the U.F.O. and U.F.W.O. work in very close co-operation. Each has its own separate officers, with the single exception of a common treasurer, consisting of President, VicePresident, Secretary, and a director for each federal riding. Each has its own executive, consisting of the first three officers just enumerated and four directors. The President and Vice-President of one are, by virtue of their office, members of the executive of the other and should attend its meetings. Furthermore the executive of one represents that body at all Directors' meetings of the other. Frequently the two complete boards of directors meet together, when an important matter of policy is to be dealt with.

Thus the women and the young people have 
entered a large field of service and have made their voices heard in the counsels of the men. Not only have they made their voices heard, but by their acts they have shown that they are mightily in earnest and are determined that the farmers' movement shall put into practice those high ideals with which it started out, and which womanhood has ever cherished. Something has been accomplished, much remains to be done. Until it is done we may rest assured that the farm women of Ontario will be keenly active. 


\section{CHAPTER VI}

\section{THE FARMER IN POLITICS}

Some attention has been paid already in these pages to the political activities of the organized farmers. We have seen how in the early days of Ontario development men came up from the land to take counsel together on public questions, and then we have noted the gradual disappearance of rural leaders. From time to time fitful attempts to regain position were made, attempts successful for the moment but soon dissolving, only to be followed by periods of deeper lethargy. Of all these attempts none has proved more vigorous nor more enduring than the U.F.O. in which the old parties see such a powerful rival. We are now to give some fuller consideration to the political aspect of the movement.

"Farmers in Politics" has become a favorite subject for discussion. It carries with it a strange appeal for the average citizen, especially if he be a farmer. Every day some ingenious editor is offering an explanation for its fascination but very often he shoots wide of the mark. Were not farmers always in Ontario politics? Assuredly, but in what capacity? They 
functioned as the great silent partner, engulfed in the hereditary, partisan, stereotyped, political machine, that fossilizes the individual and cor- rupts the party. In that kind of politics the farmer was so deep that frequently he quite forgot legitimate interests and ignored the welfare of the country. Yet very few, the farmer least of all, realized it, and so the statement "farmers are in politics" is not, as at first it sounds, so strangely incongruous and empty. Current events teach us that the statement is full of meaning and we behold an old, unnoticed fact in its new and dazzling setting. No longer is the farmer the donkey engine of the politician, used to elevate others to high places.

Rather he chooses now to act on his own volition, elevating to position whom he will, and by so choosing, elevating himself.

It is not within the scope of this work to discuss systems of government at any length, weighing for instance the merits of party government as against group government. But it is necessary that we note some of the features and the effects of the party system which we now have, in order to understand the attitude of the farmers toward it.

Political parties, whether Liberal or Conservative, are subject to the same tendencies and the same natural laws as affect individuals, or small 
groups of individuals. Political parties originated, no doubt, in legitimate divergence of opinion on questions of sufficient importance to arouse strong feeling. The feeling varied in degree of earnestness, the more earnest influencing the less earnest until divisions were firmly established in party form.

Farmers, like others, were absorbed in these parties and theoretically had just the same opportunity to wield an influence as any others, but owing to the isolated manner of their living, they gave little thought to collective action. Individualists in ownership, in effort, and in . thought, what more natural than that they should give scant attention to what was going on in urban industry, and only recently get the idea of co-operative effort as a means of benefiting their industry? John Brown and Alex. Smith, living the same kind of life side by side, whose economic interest was the same, and whose political interest was the same, conscientiously and successfully did the best they could to destroy any political influence they might exercise by cancelling each others votes on election day. Aside from the "outing" they might just as well have paired and remained at home, for all that their effort advanced the choice of a representative.

Such loyal supporters of party are not the 
- deciding factor in elections. Rather it is those who think independently on the issues at stake.

$\checkmark$ Now farmers, composing about one half of the population, were fairly evenly divided between the two old parties, and the more even the division, the less their influence in directing the policies of the nation. To demonstrate this fact we have only to cite the case of a large and fruitful township in a western county containing 76,000 acres of farm lands, with not an incorporated urban municipality within its boundaries. The line of agriculture followed is mixed farming and the population is of English and Scotch descent. At the time of the Reciprocity Election in 1911 the township contained about twelve hundred voters.

The reciprocity issue was one which affected farmers vitally. It was not a matter of little good or little harm; it was a measure that would be attended by far-reaching results, and these twelve hundred people were called upon to register their opinion at the polls. When the ballots were counted there was just a difference of five votes in the majority from that recorded * at the previous election. To those who have lived long in the country and know conditions intimately, this is but a typical example of how party affiliations held first place and beclouded 
the judgment that men otherwise might have exercised in arriving at a political decision.

Many similar cases might be enumerated, for . they are freely found and they lead us to enquire for a cause. Chief among contributing factors* was the manner of our political education. From infancy to manhood the home atmosphere was laden with hereditary, partisan influences, generally following the leanings of the male ancestry. In rare cases only did the female. members of the household take an active part in politics and thus they lacked positive influence. The predominating sway came from the father. of the home.

Moreover, the literature entering the home, including the party newspaper, was chosen by the same head also. The newspaper fed him with propaganda and he reflected the thought of the newspaper. Thus, during their most impressionable period, our youth were subjected to highly partisan teaching. As they attained . manhood they continued with the paper which delivered to them facts, partly told, true perhaps, but not all the truth. These half truths were supplemented with arguments prepared by able men, who were not always writing what they believed but what they were paid to write. Stated in other words, men who had. capitalized their ability and sold it to the less 
able than they, were the instruments of the press. The press in turn was the instrument - of money. Money then, rather than conviction,

- was moulding public opinion. The brains that should guide the nation had yielded place to organized grasping, and the sordid influences of those who desired wealth only became the chief directing agency.

In their hands the press became divided into two factions, each faction with adherents both in town and country. Bitter, political partisan warfare ensued. Journals that tried to maintain an independent course and give honest and truthful discussion of public questions continually had to yield to the powerful interests arrayed against them, or cease to exist. As an illustration of how these partisan papers affected the situation, a case that came under the writer's notice may be quoted.

A farmer of Conservative leanings, who for many years had taken two leading Tory papers, had been induced to discontinue one of them and substitute therefor a Grit paper. The reading of this for a time modified his views on many things. A neighbor of his, with whom he was on the most intimate terms, read the two Tory papers. One day they met, and falling into a political discussion they disagreed. "Why don't you stop one of your Tory papers," said 
the former, "and take a Grit paper instead? Then you would get both sides of the question and could form a better opinion on any issue." The answer was full of meaning. "Oh," said his friend of the two Tory papers, "it is just this way. Suppose you and I cannot agree on some matter and we call in a third party to settle the dispute. If I tell him all truth, and you tell him all lies, how is he going to make a just decision?"

Thus the influence of the party press was at times supreme in moulding public opinion. Each party was fed by its press with the partisan * views calculated to stimulate narrowness, and suspicion of the other party. So great was the efficiency of the press in carrying on partisan propaganda, that issues could be camouflaged by raising cries of race and religion. As an example. one might take the general election of 1911, supposedly fought on the issue of reciprocity, but really on the score of race and religion.

But once let that unbounded confidence in the press be shaken and a new order of things was sure to result. Let the masses of the people begin to think for themselves and woe betide the party heeler. There comes to mind a noted saying of Sir Wilfred Laurier, "The people must be heard, trust the people," and another of Sir John A. Macdonald in which he speaks of the rural people as the "great steadying influence." 
1 The people to be trusted and their influence to be steadying must be thoughtful and intelligent.

- The craze of party must be cured.

The first indication of a reawakening, independent, political thought in organized agriculture came in the closing years of the last

- century. It was accompanied with a desire to induce the existing parties to live up to preelection promises, and to implement doctrines advocated by themselves. This line of action reached its height in 1910 when the monster delegation proceeded to Ottawa, pressing upon the Laurier Government, then in power, to approach the United States with a view to lowering the tariff. The practicability of that line of action can be best judged by the results obtained.

The political aspirations of the U.F.O., - originally were very similar. Leaders and members did not contemplate entering the political field actively, but by education to enlighten the farmers on economies, and awaken them to the true relationship of politics to their industry. This objective could only be attained through the circulation of literature, and through public addresses by speakers reasonably free from partisan bias. Much difficulty attended the securing of such speakers. Party ties are hard to sever, both for speaker and for listener. The dark, discouraging days of early organiza- 
tion will not soon be forgotten by those who took part in the movement. Some way had to be found of arousing sufficient interest to make farmers think, even if it hurt.

In the days of horse-drawn vehicles for pleasure, one frequently noted a dashing team on one side of the street and a tired, moping delivery horse on the other. The team gave an observer the impression of somehow being proud of their job and conscious of their merit, while the delivery horse showed no interest in anything. The team had a will of their own, as was shown by the care with which the driver handled them, while a lash of the whip meant nothing to the delivery horse other than that he quickened his pace somewhat.

Looking back now, one would think that the early U.F.O. leaders must many a time have pondered this very picture, for they went directly at arousing in the farmer respect for himself and his job. Was it not agriculture that they were out to help primarily? Then demand a square deal for agriculture, and on the basis of agriculture rally the farmers. In * other words, arouse in the farmer a class consciousness.

The programme was as successful as it was direct, and by that plan of action it was only a step to political action, as sure to follow as day 
follows night. The rural people did as all other * men have done. Once class consciousness possesses men they demand a share in government, and the U.F.O. was no exception. When the step would be taken was only a matter of time. It merely needed the conditions that would crystalise into action the opinions already formed.

- Such conditions appeared when in 1918 the Dominion Government cancelled the military exemptions granted to all young men between the ages of nineteen and twenty-two years of age inclusive, actively engaged in agriculture. This action dealt a severe blow to agriculture, " more severe than to any other industry. Any one familiar with farm life knows that the skilled and efficient workman in agriculture is the young - man of just this age. He is the hustler. He it is who runs the tractor and the gas engine, the three or four horse team, and machinery gener-

- ally. Moreover, not only is he the mainstay, but he is the prospective future owner of the homestead when the parents cease to operate it. But this boy, who had been exempted on the ground that the empire needed food just as urgently as it needed soldiers, now had his exemption cancelled, and was called to the colors. The decision of the Government was particularly onerous to agriculture because the 
cancellation took place right at the commencement of seeding when hours meant bushels, and when every farmer was keyed up by the exhortation of the Government to produce to the limit.

Work practically ceased on hundreds of farms . and the office of the U.F.O. was deluged with letters asking what could be done. From early. morning till late at night angry men sought the office asking that some action be taken to impress upon the Cabinet the view of agriculture that a mistake had been made.

The executive of the U.F.O. had no other alternative than to tender its best services to the rural people. They assisted in organizing a delegation of farmers to Ottawa to voice rural opinion. A circular letter was sent to all township clerks, notifying them that if their municipality wished to give expression to their views they should send representatives to Ottawa on May 14th, 1918. About the same time a letter was received from Quebec, over the signature of Jean Mason, secretary of the Comptoir Co-operative de Montreal, asking what action Ontario was taking. Reply was made that a delegation was being sent, but that if Quebec decided on action they should deal directly with the Minister of Agriculture, Hon. T. A. Crerar. In a few days, a letter from Mr. Crerar notified Head Office that arrangements 
had been made for a Quebec delegation to interview the Government on the same day as that proposed for Ontario.

When the Ontario delegation arrived, three thousand strong, they were met by one of equal "strength from Quebec. French speaking Catholics, Irish Catholics, and Orangemen forgot ancient feuds and mingled as brothers. A new community of interest was engendered, and a feeling grew up that, after, all, they were all Canadians. This huge crowd of representatives was met on behalf of the Government by Premier Borden, Hon. T. A. Crerar, and Hon. N. W. Rowell, while Manning Doherty and W. A. Amos spoke for Ontario and Hon. J. E. Caron spoke for Quebec.

The representation made to the ministers was that if they considered men to be more necessary than food, then they were right in taking them, but it was idle to take the men and expect food * to be produced at the same time; that in any event, the men should not be taken until harvest was over, for if taken in the spring they could not be trained for the trenches until winter when little active warfare was carried on, but if taken after harvest they would be ready for spring

- activity. To these representations Premier Borden did not give a very sympathetic reply.

But the farmers were in earnest and were 
determined to register their complaint before the members of Parliament. Therefore, in a letter addressed to Hon. E. N. Rhodes, the speaker of the Commons, they requested a hearing before the bar of the House. This being refused by the Premier, the farmers formed in a huge procession and marched to the doors of the House, where they were denied admission. (Several days later, Mr. Vien succeeded in having the text of the remonstrance placed on Hansard. For a copy of this text and also of the correspondence see appendix.)

This literal shutting of the door in their faces* did more than any one thing to cause the political upheaval which has since taken place. Liberals and Conservatives alike denounced the Government, and threatened that when opportunity offered they would not forget the reception tendered them at Ottawa on May 14th, 1918. On June 7 th, at the huge convention of over three thousand farmers held in Massey Hall, future activities formed the theme for discussion. Bitter reproaches were hurled at the autocratic cabinet, while many pleasant references were made to "our fellow farmers of Quebec." As speaker after speaker advised political action as soon as opportunity offered, a feeling of entire unanimity took possession of the meeting. 
Little did they think that a test of their sincerity would be so soon applied in a remote - riding in the north. In Manitoulin a Provincial by-election was to be held in the autumn, and the farmers of the island, many of whom had been at Ottawa and also at the June convention, talked of placing an independent candidate in the field. At a convention of the clubs it was decided definitely to take this step and at a later convention Beniah Bowman was chosen to contest the riding.

All the force of the Government was centred 1 in the fight. Ridicule and slander of U.F.O. officers featured the tactics of the Government - speakers. Accustomed to the old time party machine they had failed to note the fact that U.F.O. officers on whom they poured scorn and vituperation had practically nothing to do with the campaign. The local clubs themselves had decided on action regardless of central officers, and it was not until after the candidate was in the field that Head Office was called upon to

- assist in furnishing speakers. Records indicate that the farmer speakers paid scant attention to the biting misrepresentation of the government orators, but appealed rather to the reasoned judgment of the electors. As a result of the campaign in this riding, which had for many years been strongly Conservative in politics, 
Mr. Bowman was returned with the comfortable majority of two hundred and forty. Within a few months, in the by-election in North Ontario, Mr. Widdifield, the farmer candidate, was also victorious.

Success in these two by-elections greatly added to the confidence and self-respect of the farmers. Speaking generally, the U.F.O. clubs grew in numbers very rapidly, and from all parts a desire to take active, concerted action in the impending General Provincial Election was expressed. To this demand, originating in and emanating from the clubs, Head Office could do none other than respond.

The writs were issued for the Provincial elections to be held on October 20th, 1919, and in the meantime only slight preparations had been made by the general executive and officers for assisting the clubs in the local ridings. Thus a committee, consisting of E. C. Drury, W. C. Good and Manning Doherty, was appointed to place in collective form the scattered ideas embodied in resolutions passed by delegates assembled in the annual conventions, and out of these to evolve a provisional platform. The result of their labor was the following document, "Whereas the rural population of Ontario has been declining for many years, being now 139,000 less than it was in 1881 , and this in 


\section{THE STORY OF THE U.F.O.}

spite of natural increase in population, immigration, and extension of settlement;

AND WHEREAS rural life has been rendered difficult and trying, and farm production has been checked;

- AND Whereas the present condition in the rural districts is justly attributable to the unequal rewards of farm and town industry, owing to the dominance, in Parliament and Legislature, of privileged urban interests;

And Whereas the Provincial public debt has increased at an alarming rate (now exceeding 100 million dollars) and the annual expenditure of the Province has increased almost five-fold in the last 15 years;

AND Whereas both of the old parties are responsible for this state of affairs;

Therefore, We, the United Farmers of Ontario, deem it our duty, to ourselves and the Province, to seek independent representation in the Legislature, with the following objects;

1. To cut out all expenditures that are not absolutely essential.

2. To abolish the system of party patronage.

3. To limit Governmental activity respecting commercial co-operation, to legislation facilitating co-operative effort, to the keeping of accurate records, and to general education along co-operative lines. 
4. To provide equal educational opportunities for all the children of all the people, by greatly extending and improving educational facilities in the rural districts.

5. To substitute for the policy of expensive Provincial highways, a policy of organized continuous road maintenance, and of making good roads for all rather than high-grade roads for a few, the cost of road construction and maintenance being equitably distributed between city and country.

6. To promote a system of forestry which will * maintain and increase the public revenue from this source, protect and perpetuate our forest resources, re-forest the waste places of Old Ontario, and encourage municipalities to engage in forestation enterprises.

7. To encourage and cheapen Hydro Electric development and maintain effective public control over it.

8. To enact and enforce such prohibitory legislation against the liquor traffic as the people may sanction in the approaching referendum and as lies within the power of the Province. Prohibition is an integral part of the Farmers' Platform, and the U.F.O. will use its influence in that direction.

9. To extend the policy and practice of Direct - 
Legislation through the Initiative and the Referendum.

10. To apply the principle of Proportional Representation to our Electoral methods."

This platform, along with other statements of principle and additional data, furnished a basis

- for campaign activities. It should be noted that not even yet did the farmers desire, nor did they regard themselves as attempting to form a new party, but rather as making an effort to return a number of independent representatives who would stand for the principles which they enunciated, principles that were not merely sectional but national in that they were in the interests of all the people.

In no case were the electors urged or advised to place candidates in the field by the central executive, Head Office giving assistance only when requested to do so. Enthusiasm ran high and by nomination day in sixty-four ridings supporters of U.F.O. principles were in the field, out of which forty-four were returned with large

i majorities. Thus the U.F.O. representatives were the most numerous of any one group in the legislature, yet not numerous enough to form and carry on a government by themselves.

When the elected representatives assembled, subsequent to election day, three alternatives were discussed as possible courses for immediate 
procedure. The first was to form a group government by giving Cabinet representation according to elected numerical strength. Such an arrangement would have given two seats each to Liberals and Conservatives, one to Labor, and the rest to the Farmers. Thus a government in which all parties would have their fair share of responsibility would have had an opportunity to function. Another plan was to refuse to form a government on the ground that as no party had a working majority over the combined opposition it was unfair to ask any leader to take the responsibility. This would necessitate an immediate appeal to the people. The third plan was to form an alliance with Labor, not a fusion but simply a working alliance.

All these alternatives were discussed at length and each had its adherents. The last named plan was finally adopted, two cabinet seats falling to Labor as their just share. Then began the difficult undertaking of forming a cabinet and getting a grip of the public business. Some idea of the greatness of the task can be gained when it is stated that only two of the elected farmer members had ever sat in parliament before and hardly any one member was personally known to any other. Of the long negotiations entered into it is not within our province 
to write here, as that will form the substance of another story. It is sufficient to record that in forming the cabinet (whose names appear on page 155) the Government leader, the AttorneyGeneral, and the Minister of Agriculture were chosen from outside the elected members.

The success at the polls achieved in Ontario by the United Farmers gave courage to rural people all over Canada and prompted them to turn their attention to the political citadel at Ottawa. Whenever a by-election for the Dominion House was held in a predominantly rural riding, a farmer candidate entered the contest. R. H. Halbert, President of the U.F.O., although a resident of Dufferin County, was asked by the electors of North Ontario to be their standard bearer, and in a particularly difficult fight was elected with a good majority. Glengarry next returned J. W. Kennedy, East Elgin returned S. S. McDermand, and from the far north Temiskaming sent Angus MacDonald. The confidence inspired by this continued success will undoubtedly have a vital bearing on the outcome of the general election looming up in the immediate future.

- These electoral skirmishes gave a distinctly political tendency to rural gatherings. Questions of public policy, systems of government, and the responsibility of parliamentary repre- 
sentatives to their constituents have been freely discussed by U.F.O. speakers at meetings and picnics, women and men alike taking a keen interest in all that was said. Thus there has developed in the rural electors a vision of their personal responsibility to the state, party ties have been weakened or destroyed, and success at elections, so often regarded hitherto as an end in itself, is now taken merely as the means to an end. Since the association is generally con-. sidered, and quite rightly so, to be the active force that has made such progress possible, the net result has been a marked impetus to the U.F.O.

One of the most unique features of the political procedure of the United Farmers is their method of forming their platform. Being ultra-democratic in spirit and in doctrine they attempt to carry this principle into all their efforts. Resolutions from the various local clubs relating to public matters are sent to Head Office and laid before the delegates assembled in annual convention. Here they are discussed, and if endorsed, they are placed in a tentative platform and sent back to all the clubs for discussion. Failing serious criticism, the result is the provincial platform, or in the case of the National Platform it is passed on to the Canadian Council of Agriculture. The Council 
may accept it or perhaps amend it, and send it back to all the Provincial annual conventions for endorsation. It then becomes the national platform of organized agriculture throughout Canada. Owing to the suddenness with which election contests have been sprung it has not always been possible to carry out this full procedure, but it is the process which the United Farmers hold as a practical ideal and which they have been able to live up to pretty well.

Concerning the record of the farmer representatives in Parliament much could be written, but adequate treatment would require more space than this chapter permits. When policies initiated have had time to work out the results will form the material for another study. Just here we must content ourselves with noting that in the Ontario Legislature several issues of farreaching importance have had to be dealt with and have been faced resolutely. At Ottawa a firm stand has been taken on questions such as the Tariff, the Merchant Marine, the National Railways and International Relations. What the future holds is only forecasted by what the farmers have already said and done. Their hope for making a permanent contribution to the national life rests in the thoroughness with which they are possessed by lessons learned while walking up and down the field behind the plow. 


\section{Ontario Farmer-Labor Cabinet, 1919}

Premier..............Hon. E. C. Drury....... Barrie Minister of Highways..... Hon. F. C. BIGGs.......West Flamboro

Minister of A griculture. . HoN. MANNING DoHerTy. . Malton Minister of Education.... Hon. R. H. Grant .... . . Stittsville Minister of Lands and

Forests............. Hon. Beniah Bowman....Long Bay Minister of Mines........ HoN. HARRY MILLS....... Fort William Minister of Labor........ HoN. WALTER Rollo...... Hamilton Minister without Portfolio. Hon. Dougai CARMICHAEL. Collingwood Attorney-General........ Hon. W. E. RANEy....... Toronto Provincial Secretary...... Hon. H. C. Nixon....... St. George 


\section{CHAPTER VII}

\section{STOCK-TAKING}

In days gone by there was a familiar song which had for its refrain "the only independent man is the man behind the plow." The refrain was catching, and was sung lustily, not only by those who had never stood between plow handles, but also by many honest farmers themselves. No more striking illustration of the fact that the most solid and contented citizen is the prosperous farmer could be found than these same singing agriculturists. But unfortunately many farmers did not sing that song. The fell clutch of circumstance had taught them the true character of their independence and the shallow sentiment of the refrain. The farmer was free to rise at five or seven, to plow today and harrow tomorrow as he chose, but when debts came due and market day told its tale, he learned that of the larger collective, economic and intellectual freedom, he enjoyed comparatively little. Of individual, competitive freedom he exercised much, but when he came to employ his wits and his strength in competition with other classes he learned how helpless he was. 
His independence was not so clear and farreaching as at first glance it might seem.

Collective independence stood out to the eyes of farmer leaders as the status to be striven for. In the previous pages we have seen how valiantly they have struggled and what progress has been made. Very much has been accomplished, and now as we survey the whole, our attention is first attracted to the organization. We see the entire province dotted with clubs, all knit together in a web centreing in Head Office. From the outskirts to the centre and from the centre to the outskirts in this network of activity, people are passing, messages are being carried, and ideas exchanged. Here the commercial company is functioning, there the paper is doing its work, and everywhere members are coming together for consultation. The organization, in all its completeness, is the first vivid impression.

Noting this, the question is at once suggested, what in a vital sense does it stand for. Before the United Farmers were ever heard tell of the individual farmers were just as busy, they were raising just as much produce, and were apparently performing their function in the national life. As a matter of fact, however, their efforts were one sided. So much attention was being paid to production that very little notice was being 
- taken of the final results. The farmer was not considering his occupation from the standpoint - of the body economic. Too often he was working at cross purposes with his neighbor.

In some measure at least, that has been modified. Men and women of the country are thinking beyond their farms and beyond their own community, and are putting their thoughts into operation. They are acting collectively, and that is what organization makes possible. A host of men and women have been fired with a will to make agriculture a great and respected industry. In this host are many who are lukewarm; a majority probably have not yet caught a vision of what it all means. But amongst the throng are many who see and cannot be daunted, and whose spirit is gradually spreading through the ranks. Outside the ranks are many farmers who are watching and hesitating, and who have yet to be brought in. The organization is the medium through which the dauntless ones can work, and by which all, as they see, can exert their strength in a given direction. At all odds an efficient framework or organization must be preserved.

- But anyone who has scanned the pages of history or has had much to do in concerted action with his fellow men, knows very well that no organization can live and prosper unless it be 
animated with an active, pulsating life. The mere machinery of organization counts for very little. Organization involves far more than' machinery, and particularly it involves spirit and action. If anyone requires a mental picture of what happens to a great organization once interest abates, he has but to reflect on the record of the Grange. At one time that great association held rural Ontario in its hand. It offered a task and carried a message for a multitude of farmers. It touched intimately their lives and interests. With advancing times those : interests became greatly changed, and the Grange failing to keep abreast of those interests soon lost its appeal. The spirit of the movement waned, and as it waned, the organization dwindled almost to the vanishing point. In this picture of a once prosperous, farmers' association, fallen into decline, the leaders of the U.F.O.' have a constant warning of what must inevitably happen if their organization fails to keep abreast of the times and do a work sufficiently vital to enlist and retain the active interest of its members.

Yet no one would minimize the difficulty of maintaining interest. The problems with which the U.F.O. has grappled are enormously difficult of solution. It has proclaimed as its task the correction of the injustices under which not 


\section{THE STORY OF THE U.F.O.}

only the farmer but other classes suffer. "Equal opportunity to all, special privileges to none."

"The correction of injustice carries a popular appeal, it sounds well, men and women are attracted by it, and great things are hoped for immediately. But, on close investigation, the channels of injustice have been long developing, and they run into a multitude of ramifications. Take for instance the case of a farmer marketing - his load of hogs. Before the U.F.O. took a hand in the marketing process he first of all sold to the drover. The drover in turn was dependent on the packer, while the packer was subject on the one hand to the foreign market and on the - other to the banker. The banker in turn is under the thumb of the great commercial banks financing international trade, while, with it all, governmental regulations are so mixed up that the whole complex of factors becomes a maze of " intricacy. At every stage there is infinite possibility for injustice. Yet the farmer has declared that he will correct this. He does not get very far until he finds, in the abattoir or the bank for instance, that he must look to men for assistance who are not farmers, and who are not schooled in U.F.O. principles. These men are the product of our schools and similar institutions. Thus he finds that school, and church, and every other educational agent is very 
vitally connected with the price that he receives for his load of hogs.

In declaring for justice and setting out to realise it, the farmer has undertaken a very large order. Men outside his association, who realize the size of the job, often laugh at him, but let no one forget that he has already made some progress toward his goal. He has attacked those phases of weakness and injustice which come closest to him and which are most obvious. For instance he has seen the folly of grinding away alone on his own little hundred acres, regardless of how his neighbor may be conducting his farm, or how his fellow farmer on the prairie may be marketing his wheat. In some * measure he has learned that farmers, wherever they may live, have much in common, that the prosperity of the whole body is measured by the prosperity of each individual, and that any prosperity desired can be best attained through collective action. By co-operating, as a result of . organization, he has already wiped out some glaring commercial abuses in the marketing of his products, and has revived a splendid community spirit in hundreds of localities throughout the Province.

But the measure of his success is at the same time the measure of his danger just now. The farmer who has "joined up" has expected great 
things, and has expected them immediately. But even as injustice has been a long time in entrenching itself securely here and there in our national and community life, so justice must toil - tediously to drive it forth. Reforms are slow to become well established. One might cite countless examples. Think, for instance, of the bringing about of free trade in Great Britain. Freedom of trade was proclaimed in Great Britain seventy-five years ago and those who have stood for this principle have been compelled to wage a constant fight against those who would overthrow it. Even now after these seventyfive years we find interested parties managing to have protective duties placed on numerous articles. Add to this that the measure came in the first place only after decades of agitation, and one sees how slowly privilege yields ground. In view of this, and with the certainty that relief from wrongs cannot be brought about as speedily as many members thought certain, the U.F.O. is likely to suffer from a loss of interest on the part of disappointed ones.

This points immediately to a further danger. It is new to the U.F.O. but it is old in history. Let us think of the U.F.O. as the latest phase but as only one phase of the great farmers' movement in Canada. In the opening chapter we noted how almost a century and a half 
ago farmers banded themselves together into Agricultural Societies. These held the stage for years, but interest waned and they yielded place to the Grange. The Grange then had its day, in turn declining and yielding place, for a time at least, to the Patrons of Industry. The Patrons after a brief space, as such disappeared entirely, being succeeded by the Farmers' Association and again the Grange, and now the U.F.O. (It should be born in mind that the Grange is still a strong organization.) Within these particular associations themselves there were periods of advance and decline. The fact to be noted is that all are but expressions of the one great, irresistible, pulsating life of rural Ontario, which has had its ups and downs, now going strongly, now momentarily recoiling in the face of some great disappointment. So, while there is good reason for believing that the U.F.O. embraces more elements of permanence that any of its predecessors, it would be contrary to all the teaching of history to expect that it will march steadily onward, never suffering from discouragement and disappointment. A very pressing question for leaders and members therefore will sometimes be, how to weather seasons of depression. No one, with any understanding of what has already been accomplished, will have any fear that the farmers' movement, under any 


\section{THE STORY OF THE U.F.O.}

circumstances, will die. He may have fears that it will change in form. Unquestionably change will come, but in order that such change may not be violent, with attendant temporary loss of ground, it is well for us to take stock, and by searching out the elements of permanence seek to develop and extend them.

r Confronting every farmer, there is perpetually a two sided problem, viz. how to live at all, and - how to live wisely. Men debate as to which is the more important, but all agree that they are intimately connected, and that if man is to continue in this world at all, his first worry is to - obtain food and shelter. Bloody riots and disastrous civil strife have more than once broken out under pressure of hunger and exposure. In the face of the dire necessity for food every other interest paled in significance. But with food and shelter man is then disposed to consider how he may live wisely.

- The founders of the U.F.O. were not slow in recognizing this great truth, and established at the very outset a commercial company as an integral part of the movement. Here was an agency designed to appeal directly to the farmer on the basis of his primary need. It handled goods which the farmer required, he having the assurance that so far as the company's operations were involved, the service was given with a 
minimum of profit. The same was true of goods sold by the company for the farmer. While it took time to develop the machinery, it is needless to say that the appeal was irresistible where all other arguments failed, with the result that today the United Farmers have the splendid company described in an earlier chapter. In the commercial company there lies one of the chief elements of permanence.

Passing over the necessity of wise management with the mere mention of the fact, we go on to consider dangers peculiar to the company which members should think about. One of these lies in the gross overstatement of benefits to be expected, made by enthusiastic persons in their anxiety to boost the U.F.O. Many of these benefits can be realized only after years and years of patient and determined effort. For instance it has been frequently asserted that the packers would be put out of business, the manufacturers brought to their knees, and the farmers would dictate prices, all in the twinkling of an eye, once the farmers started their own commercial enterprise. Leaving aside the question as to whether this would be a desirable state of affairs or not, it is to be noted that not only has little been done in this direction, but also that the profits of the company have been very moderate, The service also has con- 
stantly admitted of improvement, all going to show that time and experience are necessary in the development and conduct of busines enterprise. It should be repeated therefore in connection with the co-operative company that overstatement of expected benefits is sure to react to some extent, but if members as a whole take time to get a broad view of the movement, patience is sure to come to the assistance of weakening loyalty.

Another point to be noted in this connection as a temporary hindrance also is the caution required in entering new commercial fields. This affects particularly those districts where farming is highly specialized, and the handling of the products requires technical skill. For instance, bordering on Lake Erie there has grown up a tobacco industry with drying plants and other equipment. Nearby, there is the sugar-beet industry, while in the Niagara peninsula fruit is the chief item of importance.

- Farmers from each of these in turn have come more than once to the U.F.O. with the demand that machinery be created to handle their pro- ducts. Through lack of experience, funds, and trained men, the directors have had to refuse all such petitions, worthy and pressing though they have been. No doubt, all these developments will come, but in the meantime, very 
naturally too, these farmers become impatient, and many in the heat of resentment throw bricks at their own heads by knocking the organization, which, with determined support, offers them the most ready way of deliverance. So, considered from the standpoint of extension into new territory, the limitations of the company in entering new fields is a serious handicap. This must be squarely faced, and patience both cultivated and encouraged.

Perhaps there has been no more serious obstacle to the practice of the co-operative marketing business amongst farmers than their reluctance to let their produce out of their immediate hands without receiving cash for it on the spot. Cash business is, without dispute, the sane method, but co-operative business in its most highly developed form can be considered as a cash business. The factors involved can be set out most clearly by illustration.

In the early days when money was scarce and needs pressing, the settler obtained credit from his store keeper. But the merchant did not ${ }^{2}$ give that service for nothing. Not only did he, figure in his margin of profit interest to cover the investment, but also a handsome percentage to make up for doubtful debts. In other words, the customer paid for the service. Now, when the drover pays cash for the hog, and the packer 
pays the drover cash, and possibly the wholesaler the packer, and the retailer the wholesaler, the interest on the money necessary to carry the product through all these hands is charged up against the price of the hog and comes out of the producer. Not only so, but other services incidental to this method of finance are also deducted.

Contrast with this the highly developed cooperative method. It was the good fortune of the writer to meet recently two directors of the Aukland Farmers' Freezing Company of New Zealand. This is a farmers' company which slaughters, freezes, and markets livestock only. At no time does it own the product. The farmer out in the country ships in his bullock, the bullock is slaughtered, and the carcass is marked and frozen, and finally marketed. All the time the farmer is the owner of his product. Not until the carcass is finally marketed and the money paid to the company does the farmer receive his returns.

This may be an extreme example, but it indicates the length to which farmers are gradually going, and the long and continued prosperity of the company cited bears testimony to the - satisfaction given. No one who has lived on a farm can shut his eyes to the dire necessity for funds, pressing upon many a farmer. Often he 
needs his money immediately. Co-operative companies, as well as any other, can make provision for him, but let no one forget that such service must be paid for. One curse of business in the past has been that farmers have not thought about the factors involved in marketing their produce and have allowed professional dealers and speculators to assume the risk of handling it. Is it any wonder that farmers have so of ten been "done," and that there is such a spread between the price of beef on the hoof and beef on the butcher's block? The spread is intimately bound up with the unwillingness of the farmer to allow his product to go some distance out of his sight before he receives his cash in return. Encouraging progress in Ontario has already been made in the application of this principle through the co-operative shipment of live stock and the sale of grain, cheese, and other products. Further progress is inevitable, but the more the principle involved is pondered and understood, the more rapid the progress will be.

So in this way the commercial activities are making the U.F.O. a factor in solving the farmer's primary need, that of daily bread and shelter. That need will be a perpetual need, and so long as the service is right, the U.F.O. as a business enterprise will be slow in perishing. Here is an element of permanence, and it is 
essential that leaders give close attention to the conduct of the company to make very sure of its success.

But, after all, the business appeal is nothing more than the basis for a higher appeal. Were there no U.F.O., farmers would still continue to secure daily bread and to live. We must search deeper therefore for what is further - implied in the term "equal opportunity." Not only is the farmer to live, but, with equal oppor" tunity, he should live well. Certain, connected passages from a well known book by Carlyle will bear quotation here as illustrating further essentials.

" "Two men I honor and no third. First the toil worn craftsman that with earth-made implement laboriously conquers the earth and makes her man's. . . . . . Toil on, thou are in thy duty, be out of it who may; thou toilest for the altogether indispensable, for daily bread.

"A second man I honor ...... Him who is seen toiling for the spiritually indispensable; not daily bread but the bread of life. ....... These two in all their degrees I honor. All else is chaff and dust which let the wind blow whither it listeth.

"Touching is it, however, when I find both dignities united; and he that must toil outwardly for the lowest of man's wants, is also toiling 
inwardly for the highest. Sublimer in this world know I nothing than a Peasant Saint."

And again,- "It is not because of his toils that I lament for the poor; we must all toil; no faith-• ful workman finds his toil a pastime. ...... But what I do mourn over is that the lamp of his soul should go out; that no ray of heavenly or even of earthly knowledge should visit him. That there should one man die ignorant** who had capacity for knowledge, this I call a tragedy."

That so many farmers with a fine capacity for knowledge have died ignorant is the tragedy of agriculture, if indeed it is not surpassed by the fact that so many are living in such a circumscribed world of their own today. It is not. suggested that farmers are more ignorant than other classes, but no one will contend that the fine intellects of the land are being cultivated and employed as they might. So there emerges an intellectual need, to satisfy which the U.F.O. is taking vigorous measures. The great aim and object of the U.F.O. is the training and utilizing of public intelligence, especially as located in rural Ontario. In undertaking thus to meet another perpetual need the U.F.O. reveals one more element of permanence.

Probably the successful conduct of this phase of the work presents.more difficulties than that 
which is concerned primarily with daily bread. Thoughts and desires are legion and men have honest differences of opinion.' Differences of opinion are wholesome, but if those differences extend to the ends of action which men regard as desirable, there can be little concerted effort. For instance, generally speaking, of late farmers have simply asked to be left alone. Their ideal was an isolated individualism in which "where ignorance is bliss "tis folly to be wise." But their native intelligence was such that many could not endure the consequences of such an ideal, and we found emerging a new ideal, that of an enlightened agriculture putting its ideas into action. The strife between these two ideals is still going on, but more and more the new ideal is gaining ground. The greater measure of adherence given to the new ideal, the more effectively will the U.F.O. advance. In respect of ideals it is desirable, when a body of citizens is involved, that they think alike.

The farmer recently has made observations on the basis of which he has reached definite conclusions. The practice of himself and his family is to rise early, to labor at physical toil for long hours, and with a brief glance at the daily paper to retire early to profound sleep. He comes to town and he finds work commencing at eight or nine o'clock in the morning and, 
generally speaking, stopping at five or five thirty in the evening, with Saturday afternoon off and many holidays. While much of this spare time is given up by many to gaiety and wasteful folly, not a few take advantage of spare time and opportunity to acquire knowledge. The constant mingling of human beings in urban centres, in whatever condition, has the further effect of sharpening their wits and making the individual dextrous in employing what knowledge he has. The farmer's conclusion is that he himself would be well advised to concentrate less on production, and to give more hours to the study of how to live well.

The result of this conclusion has been nothing short of marvellous. All up and down rural Ontario today we find a rewakening interest in recreation and social life. Hours and even days are given over to discussions and meetings. The effects of these are now seen both in the home and in public matters. Already they have made the U.F.O. a power in the community and in the state. If anyone who has had the privilege of attending many annual meetings of the U.F.O. would have a vivid picture of what has happened, let him contrast the nineteen hundred and twenty annual convention with that of three years before. Instead of the irresolute, groping crowd of the 
former year he will find in last year's picture an orderly, tolerant, and self respecting assembly. x Learning thus to respect himself and his calling, he is out to command respect on the part of others by developing in the ranks of agriculture men and women of merit. As noted already in another connection, in speeches of prominent, political leaders, the farmer was looked upon by other classes too much as a rustic of simple habits and small mind. The pity of it was that he accepted that judgment, time and again - designating himself as "only a farmer." But "that is no longer true. His mind is active. - He is measuring the intelligence of agriculture against the intelligence of other callings, dis- puting for leadership. Let no one fancy that it is an empty challenge, full of sound and fury.

- The farmer has the qualities of heart and mind that count, and it becomes a question of patience and wise leadership how far the challenge may be realized in victory. Of the credit for what has been accomplished so far, the U.F.O. can claim a great deal; of responsibility for further development it must bear the immediate brunt.

In view of that responsibility it is necessary to take cognisance of an imminent danger, threatening serious difficulty, if not destruction. It lurks in political action. Already we have 
noted how inevitably the United Farmers were drawn into the political arena. They stood for principles rather than for party, and seeing small hope of realizing those principles through the medium of the old parties they were led to take independent action. Now politics have always held a strange fascination for men with active minds, and the farmers, with minds alert, have temporarily, too many of them, been captivated with political manifestations. The only organization, visibly active in politics in . the past has been the party machine, and it is small wonder therefore that so many United Farmers, as well as other electors, view the U.F.O. as nothing more than a third political party. They think in terms of the old political. machine. No view could be more shallow and dangerous, but if it is not to gain ground, leaders must keep their heads level, and love of glory with the "spoils of office" well in check.

It is well for us therefore to determine what a . political party is, in fact. Today it has come to mean little more than a human machine designed to keep one set of men out of office and another set in, who may enforce their wills upon the whole body. Merit undoubtedly plays a large part, but unfortunately expediency seems too often to be the deciding factor. Party. politics has thus become an insincere game in 
which the party itself has become the consideration rather than the welfare of the country.

To expect that any body of electors can suddenly break with all such conceptions is to court disappointment. Old affiliations and associations die hard. But the U.F.O., as stated, came forward with aldifferent purpose, the demand t that justice supersede expediency. Thus instead of legislation passed and administered regardless of merit, a cause should be judged on its merits, and be so dealt with by governments. - On this principle, should a cause be wrong and be espoused by any group of legislators, it can only lead to disaster. The principle which the U.F.O. has enunciated has taken a mighty hold on electors, and should that principle be ignored, it must surely be the destruction of those who enunciated and in turn violated it.

* Once this truth is appreciated, it must become clear that the U.F.O. is far more than a political party in the accepted use of the term. True, it is a party, in that it comprises a group of electors, but from what has been said in former

2 chapters, the contrast between the functioning of it and the old line parties easily demonstrates the immeasurably greater task that lies before it.

- While government is one prominent manifestation of its activity, let no one be so attracted by that as to overlook the far greater work being 
done quietly day by day in the clubs on the concession lines. Here ideas have their birth, and in the natural course grow into the public opinion which all governments and administrators sooner or later find irresistible. In nursing and training private and public opinion the U.F.O. performs its basic task. On this its leaders must continue to concentrate their best thought.

According as the true nature of the task is learned by both those within the organization and those without, whether they be farmers or not, there will be an increasingly large measure of co-operation amongst all citizens. Co-operation is the watchword of the association, and as the members co-operate they make progress. More • and more, men and women are coming to realize that no man lives unto himself but that his prosperity has some bearing on the prosperity of many others. So all thinking farmers seek. to extend the spirit and practice of co-operation to classes other than agriculture. That does. not mean that the U.F.O. is to be thrown open to everybody, but it does mean that the U.F.O., as the farmers' organization, should be ready to co-operate with the Labor Party, the Manufacturers' Association, or any other organized group on fair terms. There have been towns and cities from time immemorial and there 
- probably always will be, and all history proves that when kindly relations have existed between town and country all has gone well. Un-

- fortunately cities have usually assumed a domineering attitude with painful results to both. A shocking example of what a feud between town and country may lead to has been seen during the last two years in Austria. Proud and haughty Vienna is cordially hated by the surrounding farmers, so much so that the farmers will not even sell their produce to the city. Thus, side by side, you have a well fed rural population and a starving, dying city. Cooperation should embrace both town and country.

Particularly is this true of small towns and villages. Anyone who has lived for any number of years in the country will remember that when he came to town the merchant showed an amazing interest in weather conditions and the crops. Why did he do this? Simply because he understood very well that good crops meant more money to spend and better business for himself. He himself, with more money to spend, could afford better support to town improvement and public undertakings generally, so that every

- town citizen benefited by his prosperity. Census figures reveal the fact that nearly all towns and villages, like the farms, are suffering for the benefit of a few big cities. A typical example of 
what is happening has received some notice in the press just recently. This little town in Lambton county, Ontario, during the last ten years has lost one quarter of its population while its municipal tax bill has multiplied five fold. Not even civic improvements have been sufficient to hold the citizens in competition with the cities. So, it bears repeating, that the interests of organized agriculture and the interests of country towns are very closely bound up together.

Here again there is striking evidence of the • dangers lurking in political action. Necessarily the merchant and agent in the small town has a close connection with the manufacturer and the bank, and to a very great extent is dominated by them. The farmer, goaded to complaint, strikes * out at the big man behind the scenes, and in his fury anathematises everyone connected with him, including his merchant and agent. Too . frequently, he does not stop to size up the situation and see how so many small business men, against whom he is railing, are really drawn into the same net as himself, and are little more than tools in the hands of the men higher up.

On the other hand, the merchant and his town * neighbor have so far suffered from confusion of thought. They have enjoyed a comfortable existence and have kindly feelings toward the 
big business man who places in their hands his ' wares for sale. They resent the criticisms of - the farmers. This is the more natural because of the different methods of action adopted by the manufacturers and dealers on one hand, and

' the farmers on the other. The former, through years of development, have worked away in an unobtrusive manner, pressing a claim upon government here, setting up an arm of distribution there, putting a check on production in another place, occasionally making a misstep with consequent criticism, but always speaking in the most plausible terms, and with the best kind of word for everybody.

What of the farmer? He has spoken very plainly. In unmistakable language he has enunciated the principles for which he stands. In equally emphatic words he has denounced injustice, and over flagrant wrongs which have come directly to his notice he has aroused storms of public indignation. Far from moving quietly and with soft words, his action has been out in - the open, at times spectacular. Since reformers have seldom been popular in their day it is small wonder that urban people have stood aloof from these terrible farmers whom a servile press denounce as disturbers of the peace. But signs are not wanting that a change of attitude is taking place, and that town and country are 
coming to a better understanding of their common good. As soon as this undermines the work of crafty politicians who would set one against the other, and the basic work of the U.F.O. is perceived, full co-operation is inevitable. Just how that co-operation will work out in practical organization is something of a problem and need not concern us just now. The first requisite is a better understanding, and with good understanding a suitable method of action is sure to grow up.

Some good people would run ahead of their time and throw down the bars to all who would enter the ranks of the U.F.O. Lack of caution in this regard could result in nothing but disaster. A U.F.O. including other classes would no longer be a U.F.O., even though it be something entirely good. Let no one forget the age in * which he lives, the Canadian Bankers' Association, the Canadian Manufacturers' Association, the Retail Grocers' Association, the Ontario Medical Association, and a host of other associations whose membership is limited to those whose occupation is designated by the title. These associations exist primarily forthe protection of their members and the advancement of their interests. Even so does the U.F.O., and just as the Medical Association would cease to be a medical association if any 
number of its members were farmers, so the U.F.O. would cease to be a farmers' organization with members who were doctors, lawyers, and merchants. The name would lose all its significance, and the organization would cease to function in the manner intended by its founders, viz. "to advance the cause of agriculture in all ' its branches." The organization, as such, must be kept intact.

But that does not mean that as an organization it must not or cannot act in harmony with - similar organizations of other occupations. It must ultimately do this if peace and good-will are ever to reign amongst men, but no one surely has the hardihood to argue that peace and goodwill hold anything like sovereign sway yet. - Bitter class struggles have been waged in the past, are going on now, and are likely to go on for some time to come. Into this swirl of strife the U.F.O. has been drawn, or perhaps it is more accurate to say that out of the strife the U.F.O. has evolved, through a mass of unsuccessful contenders banding themselves together for self preservation. These United Farmers in their efforts are continually railed at as knockers, preaching co-operation on the one hand and deliberately making co-operation impossible on the other by attacking other classes. "How," say these people, "are we ever to have 
peace if these farmers are bent on class organization?" Well, there are different qualities of peace, and many treaties of peace have been negotiated in the past, almost all of which meant advantage to one party and suffering to the other. One is reminded of the scriptural quotation, "Ye go about saying peace, peace, when there is no peace." A simple illustration may help us to think more clearly on this situation.

The writer remembers that in the days of his attendance at public school there was a big boy who had his own way in everything in the school grounds during play hours. He was a bully and "lorded it" over the others, for no one dared to touch him because of his superior strength. But years went on and one day a new thing happened. One of his inferiors in strength had rapidly overtaken him in size and this day the two were led into a "fisticuff" in which the erstwhile champion got the worst of it. The effect upon him was revolutionary. His haughtiness disappeared; he had been forced to respect another as his equal, and he instantly manifested readiness to co-operate with his playmates.

The picture needs little application. In point of influence, agriculture has been down; it was not respected. The farmer has been the sport of cartoonists and politicians, the object of 
contemptuous pity for a host of men who measure prosperity in terms of big cities and tall - chimneys. Under these circumstances how can - he co-operate? Obviously it cannot be done, because neither he nor his rivals are in the proper spirit. There must be mutual respect, for the man that is down is in no position to negotiate, and the man on top is not likely to tolerate it. The U.F.O. is out to demand and win respect for agriculture.

The story is told that more than a century ago, when Napoleon was marching triumphantly through Germany, a German general after a crushing defeat gathered a few of his fugitive followers about him to consider the misfortunes of their land. He concluded his address to them with an exhortation to the following effect,"Soldiers, we are in no position to offer further military resistance, but we can go to our homes and teach these Frenchman how to live." With the determination to do this the Germans plodded on through succeeding decades and everyone knows with what success. From the high position to which that determination brought them they fell, but not until they began adopting the spirit and tactics which in Napoleon's day they denounced. Militarism denounced gave them prosperity, militarism espoused brought their downfall. 
Let the United Farmers, leaders and followers, learn this lesson well. Only by resolute, determined effort can they achieve success. Men are forever grasping at the shadow and losing the substance. The spectacular successes so far gained in politics and business are mere shadows, the substance is the change in the farm home, the farmer and his family. On these latter all else rests; on these all organization and effort should focus. As sure as organization and office become the chief end, just so surely will the U.F.O. adopt the practices which it so loudly denounces, and just so surely will those practices destroy its usefulness. [Therefore, , farmers, in the words of your constitution, to the task of "endeavoring to suppress personal, sectional, national, political, partisan and class prejudices, and thereby to promote the best interests of Canada as a whole." 


\section{LIST OF OFFICERS}

FIRST OFFICERS OF THE DOMINION GRANGE AS ORGANIZED IN LONDON, JUNE, 1874:

Master...........S. W. HrLL............Welland

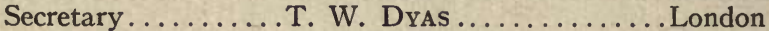

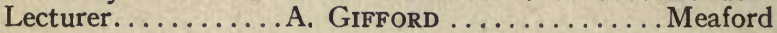

FIRST OFFICERS OF THE FARMERS ASSOCIATION FORMED IN TORONTO IN SEPTEMBER, 1902:

President.................... A. Mallory

Sec.-Treas....................... L. Smith

Directors: L. E. ANNIS, J. F. BeAM, J. LockIE WIIsON, W. L. MCLEOD

Auditors: J. W. Hyatt, Wm. McCrea.

OFFICERS OF THE UNITED FARMERS OF ONTARIO

1914

President..........E. C. Drury ............. Barrie

1st Vice-President....G. A. BRETHEN............. Norwood

2nd Vice-President...R. H. HalberT.............. Melancthon

Sec.-Treas..........J. J. MorRISON.............Arthur

Directors........... T. H. Adams............... Essex

J. F. BREEN............. Melancthon

JoHn SERvius...........Warkworth

R. H. JoHnson........... Omemee

1915

President.........R. H. Halbert.......... Melancthon

ist Vice-President.....A. J. REynoLDS . . . . . . . . Solina

2nd Vice-President.... B. C. TuCKER.............. Harold

Sec.-Treas.......... J. J. MorRISON........... Arthur

Directors............. H. HunTER........... Varney

GoRDon SALISBURY.......... Campbellford

E. A. VAn Allen...........Aultsville

Peter Gardiner.......... Corunna

R. H. JoHnson.......... Omemee 
1916

President.........R. H. HALbERT ......... Melancthon

1st Vice-President..... A. J. REynoldS . . . . . . . . Solina

2nd Vice-President...W. C. GooD..............Paris

Sec.-Treas.........J. J. MoRRISON............Arthur

Directors. .........W. H. HunTER.......... Varney

E. A. VAn Allen...........Aultsville

E. C. DRURY............. Barrie

J. Z. FRAZER ............ Burford

L. H. BLATCHFORD........Embro

1917

President.........R. H. Halbert......... Melancthon

1st Vice-President....E. C. DRURY ................ Barrie

2nd Vice-President...W. C. GooD...............Paris

Sec.-Treas........... J. J. MoRRISON........... Toronto

Directors.........W. H. HunTER......... Varney

T. H. Adams. ............ Essex

S. S. Staples............ Ida

Peter Porter.............Burford

R. S. McTavish...........Balderson

J. N. Kernighan.......... Goderich

1918

President .........R. H. Halbert.......... Melancthon

Vice-President.......E. C. DRURY ............... Barrie

Sec.-Treas...........J. J. MorRISON........... Toronto

Directors for this year and subsequently consisted of one director for each Federal riding in Ontario.

\section{9}

President.........R. W. E. Burnaby....... Jefferson

Vice-President........W. A. AMos................Palmerston

Sec.-Treas..........J. J. Morrison........... Toronto

1920

President..........R. W. E. Burnaby ........ Jefferson

Vice-President.......W. A. Amos.............. Palmerston

Sec.-Treas..........J. J. Morrison........... Toronto

\section{OFFICERS OF FARMERS' PUBLISHING COMPANY}

1918

President.........J. Z. FrazER...........Burford

Sec.-Treas.......... J. J. Morrison.............. Arthur

Directors.......... A. A. Powers.......... Toronto

J. N. KeRNIGHAN ........ Goderich

G. A. BROdIE............ Newmarket 
President.........J. Z. Fraser........... Burford Vice-President....... MANNING DoHERTY..........Malton Sec. -Treas......... J. J. MorRISon........... Arthur Directors ..........W. C. GooD............. Paris

A. A. Powers.......... Toronto

1920

President.........J. Z. Fraser...........Burford Vice-President......W. A. Amos.............. Palmerston Sec.-Treas........... E. WALTERS......... Toronto Directors......... MANNING DoHERTy .........Malton W. C. Good.............. Paris J. J. MORRISON...........Arthur

\section{OFFICERS OF UNITED FARM WOMEN OF ONTARIO}

President. .......... Mrs. G. A. Brodie........ Newmarket Vice-President........ Mrs. J. N. Foote........ Collingwood Secretary........... Miss Emma Griesbach..... Collingwood Executive Directors.. Mrs. H. WILsON .......... Georgetown MrS. FranK Webster...... Oakwood The above were also the provisional officers and executive for 1918 .

\section{0}

President.......... Mrs. G. A. BrodIE ....... Newmarket Vice-President....... Mrs. J. N. FootE......... Collingwood Secretary ........... MrS. H. L. LAws......... Cayuga Executive Directors.. Mrs. Frank WeBSTER.... Oakwood Mrs. W. N. GLENN ...... Centralia MrS. J. S. AMOS..........Woodstock Mrs. J. Alex. Wallace... Simcoe

\section{1}

President........... Mrs. J. A. Wallace...... Simcoe Vice-President........ Mrs. J. S. Amos.......... Woodstock Sec.-Treas........... Mrs. H. L. LAws......... Cayuga Executive Directors. . Mrs. Frank WeBSTER..... Oakwood Mrs. W. N. GLenN........ Centralia Mrs. H. S. Goltz......... Bardsville Miss Agnes McPhall...... Ceylon 
OFFICERS OF THE UNITED FARMERS CO-OPERATIVE COMPANY

\section{4}

President ..........W. C. GooD.............. Paris

Vice-President........ Anson GROH ................ Preston

Sec.-Treas......... J. J. Morrison........... Arthur

Directors . . . . . . . JAS. R. ANDERSON . . . . . . Mountainview

S. A. BECK.................. Cayuga

E. C. DRURY ............ Barrie

C. W. GuRnEy ........... Paris

J. Z. Frazer............... Burford

Jno. Pritchard........... Gorrie

C. F. WhitTAKeR.........Williamsburg

A. E. VANCE ............. Forest

C. F. RATH.............. Lansdowne

GEO. CARLAW ...........Warkworth

A. A. Powers........... Orono

\section{5}

President

AnsON GROH ............... Preston

Vice-President.

A. A. Powers............ Orono

Sec.-Treas.......... J. J. MorRISON.......... Toronto

Directors........... E. VANCE ............ Forest

J. R. ANDERSON ............ Mountainview

E. C. Drury ................. Barrie

C. F. WhitTAKer........Williamsburg

Geo. Carlaw . . . . . . . W Warkworth

W. C. Goop.............. Paris

J. Z. Frazer............. Burford

Jno. Pritchard........... Gorrie

S. A. BECK............. So. Cayuga

C. W. Gurney.......... Paris

L. SCHNURR .............. Shallow Lake

\section{6}

President.......... Jno. Pritchard........... Gorrie

Vice-President........ . W. GuRNEY .............. Paris

Sec.-Treas.......... J. J. MorRISON........... Toronto

Directors.......... C. F. WHITTAKER.........Williamsburg

Geo. Carlaw ...........Warkworth

A. A. Powers.......... Orono

W. C. Good.............. Paris

ANSON GROH................. Preston

J. Z. Frazer.............. Burford

S. A. BECK............. So. Cayuga

L. SchNURR ............ Shallow Lake

E. C. DRURY............. Barrie

B. C. Tucker........... Harold 


\section{7}

President........... C. Tucker........... Harold Vice-President...... ELMER LICK............ Oshawa Sec.-Treas......... J. J. MorRISON.......... Toronto

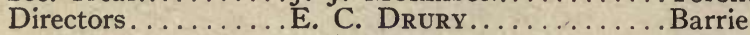

L. SchnuRR............. Shallow Lake

W. C. Good.................. Paris

A. A. Powers. . . . . . . . Orono

R. H. HalberT............ Melancthon

Wm. McCrea........... Guelph

A. E. Van Allen............ Aultsville

1918

President..........R. W. E. Burnaby ....... Jefferson

Vice-President....... A. A. Powers............ Orono

Sec.-Treas......... J. J. MorRison........... Toronto

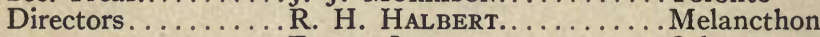

Elmer Lick.............. Oshawa

E. A. Van Allen.......... Aultsville

E. C. Drury............. Barrie

C. W. Gurney ...........Paris

B. C. TUCKER ............. Harold

WM. McCrea.............. Guelph

1919

President..........R. W. E. Burnaby ....... Jefferson

Vice-President....... A. A. Powers. ........... Orono

Sec.-Treas.......... J. J. MorRIson.......... Toronto

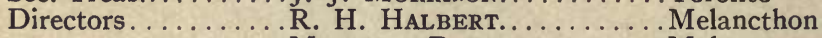

Manning Doherty ......... Malton

E. A. Van Allen. . . . . . . Aultsville

R. J. MCMILlan . . . . . . Seaforth

ELMER LICK............. Oshawa

B. C. TUCKER............ Harold

E. C. DRURY............. Barrie

1920

President.......... A. A. Powers. .......... Orono

Vice-President....... ELmer LICK............. Oshawa

Sec.-Treas..........J. J. MorRISON.......... Toronto

Directors.......... A. E. VAn Allen..........Aultsville

R. J. McMillan .......... Seaforth

J. Z. FRAZER...........Burford

H. V. Hoover............. Harold

Arthur Craise .............. Catharines

W. C. Good................ Paris

R. W. E. BurnabY.......... Jefferson 


\section{LIST OF OFFICERS}

1921

President .......... A. A. Powers.......... Orono

Vice-President....... Col. J. Z. Frazer......... Burford

Sec.-Treas.......... J. J. Morrison.......... Toronto

Directors..........R. W. E. BURNABY....... Jefferson

R. J. McMillan......... Seaforth

H. V. Hoover........... Harold

A. E. Van Allen......... Aultsville

ELMER Lick............. Oshawa

J. B. LEVERT. . . . . . . . . . Warren

R. H. Ashton............. Morrisburg 


\section{APPENDIX}

\section{THE REQUEST}

(Hansard, p. 1912.)

Russell Theatre, Ottawa, May 14th, 1918.

The Hon. E. N. Rhodes,

Speaker of the House of Commons.

Sir, -

On behalf of several thousand Ontario farmers I beg to transmit to you the following resolution just passed, and to say that, encouraged by the reception recently accorded the President of the American Federation of Labour, we are confident the request will be granted.

"That this meeting instructs the chairman respectfully to ask the House of Commons to receive him, and two delegates he shall name, at the sitting of the House this afternoon, to hear their address upon the situation in the country, and asking that democracy be honoured in the prosecution of the war, and all other matters of government."

The messenger who brings this will respectfully await an answer.

(Signed) R. H. HalBerT,

Chairman.

\section{THE REFUSAL}

\section{(Hansard, p. 1937.)}

Sir ROBERT BORDEN: Under the circumstances, I do not feel that the House ought to interrupt its proceedings for the purpose referred to. If these gentlemen would like, between the hours of six and eight o'clock, to address any members of the House who would wish to be present to hear them, there is not the slightest objection to it. 


\section{THE REMONSTRANCE*}

(Hansard, p. 2551.)

*The document is printed as prepared. The event proved that there was nothing to thank the House for.

To the Honourable the Speaker

and Members of the House of Commons

of Canada, in Parliament assembled.

\section{Mr. Speaker, and Gentlemen of the House of Commons:-}

"On behalf of thousands of farmers assembled in this city to-day, we warmly thank the House for the proof it has given that it desires to keep in sympathetic touch with the citizens from whom it derives its dignity and authority. We believe we express the sentiments of all thoughtful citizens when we say that this departure in Canadian Parliamentary practice, following so closely upon the speech to this House and the Senate, of the President of the American Federation of Labour, is an agreeable recognition of the new relationships which the war is producing, as between those who govern and those who are governed by consent.

"The portion of Canadian labour which is so vital to the prosecution of the war, and which we represent, appreciates to the full the evidence of loyalty which the House of Commons gave in August, 1914 , to the democracies of the western hemisphere in its instant support of the Motherland in her hour of need. We trust that the spontaneous action then taken will be justified by a continuation of those habits of freedom which it has long been the particular privilege of Canadians to maintain. These privileges are all the more appreciated in view of the long struggle for responsible government which was undertaken against the opposition of those who exercised arbitrary authority, and who feared the free expression of opinion, in the press and by the spoken word.

"We are sure the House will permit us to say also, that the citizens generally have observed with gratitude that the House - has shown a larger independence of thought and speech than has been customary under the system of partisan government. We should fail in the duty of being candid which is cast upon us by the readiness of the House to hear us, if we did not point out a tendency that has been observed in the House, where the public will is believed to be supreme. The increasing frankness of discussion so noticeable here, has been accompanied by a tendency to silence on the part of members of the Cabinet, who in reality are, as one of your distinguished members has said, 'Only a Committee of this House.'

"The unrest in the country which has brought about the unexampled spectacle of thousands of farmers leaving the important work of planting their crops, to come to the capital to remonstrate with the Government, is known to every member of the House of 


\section{THE STORY OF THE U.F.O.}

Commons. We beg leave to intimate that this unrest is not related merely to the special matter which was discussed with the Premier and members of his Cabinet to-day.

"We cannot disguise from the House an apprehension that the liberties, of which the popularly elected branch of the Legislature is the bulwark, may be dangerously curtailed during the period that the House is not sitting. In proof that this dread is not illusory, we would venture to inform the House that, in common with our fellowcitizens, here and throughout the country, we have observed certain innovations, the continuation of which, we believe, would be fraught with serious results to the confidence which the subjects of His Majesty have hitherto reposed in the working of that responsible government for whose unimpaired preservation forty thousand Canadian soldiers have laid down their lives.

"Will the House permit us to speak more plainly what is in our minds? We have never believed that the conditions produced by the war demanded flagrant departures from the honoured processes of the law enjoined by the Constitution, while Parliament is in session or is near assembling. We believe that reliance upon Parliament, instead of upon arbitrary authority, most effectively honours the guarantees of freedom which are embedded in the Constitution. One considerable departure from sound practice may be accepted, but repetitions of it may be exceedingly dangerous, especially under such circumstances as now beset the State.

- "We, therefore, beg leave to remind the House of several instances in which, it seems to us, the liberties of the people, and of their representatives, have not been given sufficient consideration.

"Twelve days before the meeting of Parliament in January, 1916, the authorized Canadian Army was doubled from 250,000 to 500,000 men. No British Army had ever been doubled without recourse to Parliament. That it was done in Canada caused students of British history to enquire whether anything had occurred to warrant such a disregard of Parliament.

"Though this House of Commons has inherited some of the consequences of such an innovation, we desire to confine our respectful remonstrances to more recent events.

"During this session there were riots in the City of Quebec. The House desired to discuss the serious situation thus created, and was entitled to declare what measures might be taken to prevent a renewal of such unhappy occurrences. It did not escape the notice of the country that, immediately before the House proceeded to discharge its duty, there was put upon the table a completed law, in the form of an Order-in-Council, which arbitrarily took out of its control the very question which the House of Commons was about to discuss.

"Later, there were other departures from the traditional practice of British law, by equally astonishing proceedings. An Order-inCouncil was given to the House, as a matter of information, providing for the registration of the human power of the country, and setting up an entirely new criminal code in connection therewith, by creating 


\section{APPENDIX}

several methods of punishment hitherto unknown to Canadian civilization. Surely such a departure should not have been attempted in such a manner. Punishments created without the assent of Parliament naturally tend to provoke hostility. We feel we are performing a national duty in respectfully calling attention to such conditions.

"The Order-in-Council, endorsed by both Houses on April 18 th, virtually sweeps away the Military Service Act. The resentment it has created is known to this House, members of which are known to regret that the elements of the Constitution were ignored in this proceeding; and that the method of presenting a practically executed decree, while withholding disclosure of the facts on which it was based, cannot easily be justified to the constituents of a newly-elected Parliament.

"The curtailment of the liberty of written and spoken speech, contained in the Order-in-Council, given to the public on April 16th, has caused especial concern to all who are aware of the history of free discussion in Canada and other parts of the British Empire. We are sure we need not beg the House to examine its provisions, ? in order to appreciate how a doctrine of the essential infallibility of the Government may be forced upon a free people, on pain of a fine of five thousand dollars and five years' imprisonment.

"The House, to our extreme regret, has been faced with a notification of the intended curtailment of the privilege of a member of Parliament to declare his mind, and the right of his constituents to know what he has uttered. That this unique warning to a freelyelected British assembly was halted for several weeks on the order paper, we venture respectfully to attribute to you, Mr. Speaker, as the appointed guardian of the liberties of the House, and also of the people. It has been noted that the Prime Minister, in withdrawing the measure, viewed with so much apprehension from outside the House, announced that it is likely to be re-introduced next session.

"Perhaps the House may not be offended to learn that cognizance has also been taken of a notice issued to it, within the last week, to the effect that it must curtail its discussion of vital national affairs, and withdraw from its precincts within a few days, or be summoned hither during the hottest and most inconvenient month of the year. That such a direction should be issued without recourse to the judgment of the House causes reflective citizens to wonder what has happened to the freedom Canadian institutions have hitherto enjoyed.

"Mr. Speaker and Gentlemen of the House of Commons,The disquiet of the country, of which we are the humble and inadequate exponents, and which demonstrates sadly the increasing dangers to our national unity, which, if we lose it, we shall have lost all indeed, cannot be allayed by a persistence in the courses we have so imperfectly sketched.

"Will the House permit us, with much deference, but much earnestness, also, to repeat the reminder of one of its members, that the Government is a Committee of the House vested with the 
executive powers of Parliament? The responsibility of government, therefore, is ultimately upon this House. Nothing appears to have been done to make the position of members of Parliament, with regard to the carrying out of the war policy, correspond to the status which they enjoyed before the practice crept in of making them subservient to those whom they created, and whom they may destroy.

"In this prolonged crisis of the national fate, the hour has arrived to re-establish the inherent freedom of the House of Commons. We are certain that in that restoration the people of Canada will sustain you, and that the sacrifices of war will be justified and honoured in the blessings and progress of peace."

\section{A LETTER TO HIS EXCELLENCY}

(Hansard, p. 2550.)

Windsor Hotel, OtTawa,

May 25th, 1918.

His Excellency the Duke of Devonshire, Governor-General of Canada.

"Your Excellency:-

"The undersigned, in exercising the immemorial privilege of British subjects, are confident that Your Excellency will honour the ancient practice of the highest authority of the realm, of hearing sympathetically the representations of citizens upon matters affecting the good government of Canada.

"We are encouraged to transmit to you certain information, by the knowledge that those who have preceded you as a representative of the Crown in the working of responsible Government in Canada, have been swift to regard any endeavours to depart from the constitutional usages by which the freedom of Parliament, and, of the individual citizen, has been established.

"Since Your Excellency's arrival among us, we have had every reason to be assured that Your Excellency is imbued with the conciliatory, far-seeing and statesmanlike spirit which animated Lord Elgin, to whom Canada and the Empire will ever be indebted for a wise and courageous guidance within the powers confided to him.

"We believe, therefore, that you will welcome this expression of our trust during the period of unprecedented difficulty through which the Dominion of Canada is passing.

"It is in harmony with Lord Elgin's reply to an address from the County of Glengarry, dealing with the unrest at that time, regarding the administration of public affairs, that we submit for Your Excellency's consideration the attached correspondence with the Speaker 
of the House of Commons. Perhaps Your Excellency will allow us to repeat what Lord Elgin said to the men of Glengarry, in reply to their address: 'I recognize in it evidence of that vigorous understanding which enables men of the stock to which you belong, to prize, as they ought to be prized, the blessings of well-ordered freedom, and of that keen sense of principle which prompts them to recoil from no sacrifice which duty enjoins.'

"Your Excellency will observe that those citizens whom we represent, are striving to ensure the continuance of what Lord Elgin described as 'well-ordered freedom.'

"We do not ask that Your Excellency will take action outside the lines of constitutional practice. At present we desire only to keep you informed of the increasing difficulties which appear to affect injuriously the privileges which belong to the citizens through the House of Commons.

"We beg to state to Your Excellency that we are aware that certain objections in connection with prescribed forms of approach may be cited against the course we have taken. But we are also well assured that in times like these, it is good counsel rather than appeals to form which should prevail.

"We beg respectfully to add that, in conveying with all convenient speed to those who have authorized us to act, the information of our reliance upon Your Excellency's beneficient intentions to all the loyal people of Canada, we are rendering a service to the unquestionable stability of Parliamentary freedom which all British citizens must desire to be maintained at home while it is being defended abroad."

$$
\begin{aligned}
& \text { (Signed) C. W. Gurney, } \\
& \text { J. N. Kernighan. }
\end{aligned}
$$




(68)

$$
554
$$


$=$ 



\section{PLeAse do NOt REMOVE CARDS OR SLIPS FROM THIS POCKET}

\section{UNIVERSITY OF TORONTO LIBRARY}




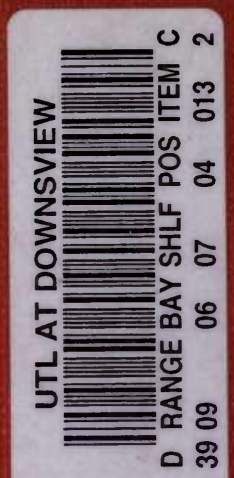

